\title{
Algumas notas sobre a base de dados Cantigas Medievais Galego-Portuguesas
}

\section{Graça Videira Lopes}

\section{(2) OpenEdition}

\section{Journals}

\section{Edição electrónica}

URL: http://journals.openedition.org/medievalista/736

DOI: 10.4000/medievalista.736

ISSN: 1646-740X

\section{Editora}

Instituto de Estudos Medievais - FCSH-UNL

Edição impressa

Data de publição: 1 Junho 2012

\section{Refêrencia eletrónica}

Graça Videira Lopes, «Algumas notas sobre a base de dados Cantigas Medievais Galego-

Portuguesas », Medievalista [Online], 12 | 2012, posto online no dia 19 fevereiro 2014, consultado no dia 19 abril 2019. URL : http://journals.openedition.org/medievalista/736 ; DOI : 10.4000/

medievalista.736

(c) IEM 
Título: Algumas notas sobre a base de dados Cantigas Medievais Galego-Portuguesas Autor(es): Graça Videira Lopes

Enquadramento Institucional: Instituto de Estudos Medievais FCSH - UNL

Contacto: gvl@fcsh.unl.pt

Fonte: Medievalista [Em linha]. №12, (Julho - Dezembro 2012). Dir. José Mattoso.

Lisboa: IEM.

Disponível em: http://www2.fcsh.unl.pt/iem/medievalista/

ISSN: 1646-740X

Data do artigo: Março, 2012

\section{Algumas notas sobre a base de dados Cantigas Medievais Galego-Portuguesas}

Graça Videira Lopes

Como a seu tempo a revista Medievalista online anunciou, desde finais de Outubro de 2011 que se encontra disponível na web, a nova base de dados Cantigas Medievais Galego-Portuguesas, plataforma multimédia que inclui a edição integral e anotada das cantigas medievais presentes nos cancioneiros galego-portugueses, as respectivas imagens dos manuscritos, a música (quer a medieval, quer as versões ou composições originais contemporâneas que tomam como ponto de partida os textos das cantigas medievais), informação sucinta sobre todos os autores nela incluídos, sobre as 
personagens e lugares referidos nas cantigas, bem como a "Arte de Trovar", o pequeno tratado de poética trovadoresca que abre o Cancioneiro da Biblioteca Nacional, assim como diversos outros recursos, entre os quais será de salientar a possibilidade de pesquisas múltiplas. Resultante do projecto "Littera - edição, actualização e preservação do património literário medieval português", projecto financiado pela FCT de 2007 a 2010, o site deve a sua concretização ao trabalho de uma pequena mas empenhada equipa multidisciplinar (que incluiu, com os jovens bolseiros e colaboradores, as áreas científicas da Literatura, da Música, da História, mas também, e é de toda a justiça salientá-lo, a área mais técnica da Informática), cujos elementos séniores (eu própria, Graça Videira Lopes, responsável geral pelo Projecto, Manuel Pedro Ferreira, responsável pela área da música e Nuno Júdice) há muito vinham trabalhando diversos aspectos do riquíssimo património que são as cantigas trovadorescas galegoportuguesas. Seja como for, o certo é que este trabalho específico da construção da base de dados (BD) foi também, cientificamente, uma oportunidade única de revisitar, na sua totalidade, e de forma global e integrada, o corpus das cantigas medievais conservadas. Foi desse trabalho que resultaram os dados disponibilizados no site, se bem que, dadas as características técnicas deste tipo de plataformas, o espaço seja pouco para justificações ou reflexões demoradas sobre os mesmos. Nas observações que se seguem procurarei, pois, dar conta, de forma um pouco mais elaborada, de alguns dos principais resultados científicos desse trabalho.

Antes, porém, não poderei deixar de fazer algumas considerações preliminares sobre a própria plataforma, a primeira das quais diz respeito ao critério que presidiu ao seu desenho. Construída com vista a uma difusão na Web, a base de dados foi pensada, desde o seu início, como um instrumento de carácter abrangente, visando um públicoalvo composto quer pelos especialistas das mais diversas áreas, quer pelo leitor comum interessado, mas não necessariamente familiarizado com a língua, a música ou o universo das cantigas medievais. Trata-se, nesta medida, de um plataforma dirigida, conjuntamente, à investigação e à divulgação, junto de um público mais vasto, do riquíssimo património ibérico que constituem as cantigas medievais profanas. Todos os recursos nela disponibilizados procuraram, pois, ir ao encontro das necessidades e expectativas destes potenciais e distintos utilizadores. Para dar apenas um exemplo, é assim que, ao mesmo tempo que anotamos com relativa abundância os textos das 
cantigas (notas explicativas, glossário, etc.), damos igualmente a possibilidade, ao leitor que assim o deseje, de visualizar estes mesmos textos sem anotações (bastando-lhe, para tal, desactivar este recurso). De resto, entre os recursos disponibilizados, e tirando partido de uma das mais poderosas funcionalidades deste tipo de instrumentos, os recursos de pesquisa serão talvez aqueles que poderão constituir uma das suas maisvalias, particularmente no que toca à investigação nos mais variados domínios. Foi esse pressuposto que nos levou a construir a página de entrada do site em torno desta funcionalidade, se bem que, na barra horizontal superior, o menu "Pesquisa" dê ainda acesso a pesquisas mais específicas, nomeadamente à "Pesquisa em toda a base" (cujos resultados incluem, não só as cantigas, mas todos os dados inseridos na BD). Também o menu "Recursos" disponibiliza um conjunto variado de dados gerais, entre os quais poderia salientar, por exemplo, e agora visando talvez um público mais lato, o que diz respeito aos "Temas", ou assuntos abordados nas cantigas.

Quanto aos critérios científicos propriamente ditos definidos para a BD, acrescentarei ainda umas considerações prévias. Na verdade, e embora os objectivos do projecto Littera fossem, no seu início, mais modestos (o projecto apresentado à FCT incluía apenas a edição integral das cantigas de amor, a que se juntava a edição integral das cantigas de dois ou três trovadores, nomeadamente dos dois cuja música parcialmente sobreviveu, D. Dinis e Martim Codax), rapidamente a equipa responsável considerou que, dadas as circunstâncias e as condições (talvez irrepetíveis) de que dispunha, os seus objectivos poderiam ser mais ambiciosos, ou seja, que teria eventualmente disponibilidade e meios para, aproveitando as potencialidades e o impulso da jovem equipa então formada, alargar o trabalho à totalidade das cantigas transmitidas pelos Cancioneiros. Embora conscientes das dificuldades desta tarefa (que necessariamente se prolongou para além do período financiado do projecto), a construção desta base de dados alargada constituiu assim, como dizia, uma oportunidade única de revisitar, de forma integrada, o corpus profano trovadoresco, até pela necessidade de responder, de forma prática e num espaço de tempo necessariamente limitado, à multiplicidade e variedade dos problemas que as cantigas ainda hoje nos colocam: dos relativos à edição dos textos aos da sua interpretação, da música aos contextos de produção, dos cancioneiros e tradição manuscrita às biografias dos autores ou à autoria das cantigas, para referir apenas os mais evidentes. Muitos destes problemas foram e continuam a ser 
objecto dos mais diversos estudos por parte de um vasto leque de filólogos, medievalistas e especialistas de várias áreas, de resto muito produtivos nestas últimas décadas, contribuições essas que de forma nenhuma poderiam ser ignoradas. Conscientes também da inevitabilidade de lapsos e falhas no que respeita a essa já longa lista de bibliografia (dadas até as dificuldades práticas de acesso a alguns trabalhos mais recentes, ou até mesmo a sua deficiente sinalização), procurámos, pois, na medida das nossas possibilidades, integrar criticamente na $\mathrm{BD}$ os muitos e, em muitos casos, valiosos contributos que a investigação "clássica" e, sobretudo, a mais recente tem vindo incessantemente a fornecer sobre as diversas vertentes desta vasta matéria e que têm permitido alargar consideravelmente o nosso conhecimento sobre as cantigas, os trovadores e jograis e o mundo que era o seu.

Mas um projecto desta natureza, pelo menos como a equipa o entendeu desde o seu início, comporta também, necessariamente, uma dimensão de trabalho directo sobre o corpus, assente na pesquisa e até mesmo de descoberta mais ou menos fortuita de dados novos, dados esses que, juntamente com as inevitáveis escolhas feitas, nomeadamente no que toca à edição dos textos, disponibilizámos igualmente na $\mathrm{BD}$, muitas vezes em forma de proposta à comunidade científica. Disseminadas ao longo dos milhares de páginas que comporta o site, muitas dessas novas propostas poderão eventualmente ser pouco visíveis, ou sê-lo-ão apenas para o especialista nessa matéria específica (que se disponha a procurá-los). Daí que, mesmo sendo impossível anotar minuciosamente todas as diferentes escolhas que fizemos em relação a propostas anteriores ou todas as variações ou alterações de dados que introduzimos em muitos campos, creio que será útil fazer, neste momento, um ponto da situação no que toca a um conjunto mais restrito de propostas ou dados novos resultantes do nosso trabalho, particularmente os que dizem respeito a aspectos problemáticos do corpus trovadoresco, até para, com esta chamada de atenção, possibilitar a sua discussão (e eventualmente a sua correcção ou o seu aprofundamento, desígnio central num projecto que se quer aberto e dinâmico). Embora muitas destas novas propostas introduzidas na base tenham dimensões múltiplas, no texto que se segue, por uma questão de legibilidade, irei organizá-las nas seguintes alíneas: 1) Dados gerais; 2) Novas propostas de leitura (com duas notas breves sobre os manuscritos); 3) Citações internas e relações intertextuais; 4) Notas biográficas 
de autores e questões de autoria; 5) Novos dados de antroponímia e toponímia; 6) Contextos e interpretações; 7) Perspectivas futuras.

Gostaria apenas de acrescentar que nestas breves notas estão declaradamente ausentes as questões relacionadas com a dimensão musical da BD, tarefa que, com todo o gosto, deixarei a cargo do meu colega de equipa e amigo Manuel Pedro Ferreira, que tão competente e eficazmente coordenou esta área específica do projecto Littera.

\section{Dados gerais}

A afirmação de que as cantigas medievais se inserem num tempo e num espaço social politicamente definido não oferece novidade de maior. A investigação mais recente, dando continuidade a um tipo de abordagem já muito presente nos grandes investigadores "clássicos", de Carolina Michaëlis a Rodrigues Lapa, tem vindo, aliás, a reforçar esta ideia, na série contínua de novos dados avançados, nomeadamente sobre a origem e o percursos dos autores ou sobre as referências antroponímicas ou toponímicas presentes nas cantigas. Abundantemente citados na presente base de dados, os excelentes e continuados trabalhos que António Resende de Oliveira, José António Souto Cabo ou Vicenç Beltran, entre outros, têm vindo a publicar em anos recentes sobre estas matérias serão talvez o melhor exemplo disso mesmo. De qualquer forma, do trabalho por nós efectuado sobre o corpus integral da poesia profana trovadoresca, todos os géneros reunidos, um dos pontos gerais que me parece de salientar desde já é a renovada constatação da ligação estreita dos textos trovadorescos com os contextos da sua produção, nomeadamente com os contextos políticos. Na alínea 6 destas notas retomarei, de forma mais detalhada e com exemplos concretos, este ponto. Mas a percepção de que as cantigas trovadorescas assentam no princípio de uma construção subtil e minuciosa, na qual, em geral, todos os elementos "significam", e, em grande medida, "significam politicamente", não pode deixar, desde já, de ser realçada. Na verdade, se a questão do alcance político dos textos dos trovadores e jograis nunca levantou grandes dúvidas no que toca a uma parte das cantigas satíricas, as que abertamente referem elementos do xadrez político da sua época (e a deposição de D. Sancho II é, neste aspecto, um dos momentos satiricamente mais produtivos), dispomos 
hoje de dados que permitem postular que a questão é bem mais vasta, e não se resume às cantigas que declaradamente "dizem ao que vêm". Fazendo apelo a recursos diversificados e por vezes mínimos, muitas outras são o que poderíamos chamar "cantigas situadas", subtil mas decididamente remetendo para um tempo e um espaço particulares. E assim, quer em cantigas satíricas desde sempre consideradas meramente circunstanciais e lúdicas, quer em cantigas de amigo ou de amor que jogam com elementos "dissonantes" (ou seja, que introduzem variações mais ou menos marcadas às normas do género), a dimensão política torna-se evidente, uma vez descodificados os elementos (toponímicos, antroponímicos, intertextuais, ou outros) que, directa ou indirectamente, lhes servem de suporte.

Estamos, pois, perante o que parece ser uma dimensão verdadeiramente estrutural da arte trovadoresca, assente num princípio que poderia ser definido como "um mínimo de recursos para um máximo de efeito". Na verdade, se este é também, embora com outra funcionalidade, o princípio detectável numa boa parte das cantigas de amigo, creio poder afirmar-se que é ainda ele que preside ao modo falsamente anódino ou "inocente" como muitas alusões referenciais carregadas de sentido (e de sentido muitas vezes político) são introduzidas no canto público dos trovadores e jograis. Na leitura global e integrada que fizemos do corpus trovadoresco este mecanismo "minimalista" (ou, se quisermos, o apelo à leitura "lenta" que fazem muitas cantigas, mesmo aquelas que não são construídas na forma do muito usado equívoco), esse mecanismo, dizia, tornou-se, para nós, evidente, determinando muitas das pistas interpretativas que seguimos. E se bem que muitos dos dados referenciais concretos que permitem esta leitura sejam, em muitas composições, ainda difíceis ou problemáticos de contextualizar com exactidão, não parece haver dúvidas de que a relação das cantigas trovadorescas com os seus contextos políticos imediatos é bem mais estreita e efectiva do que geralmente se pressupunha ou do que poderíamos pressupor a partir do punhado de cantigas satíricas que declaradamente abordam questões e conflitos desta natureza. Deixando a explicitação deste ponto para um pouco mais tarde, o facto é que, enquanto dado geral, este princípio não deixou de condicionar todas as restantes áreas do trabalho que desenvolvemos sobre o corpus trovadoresco, da edição das cantigas às biografias dos trovadores, por exemplo, motivo que justifica esta alínea inicial. Mas antes de me 
debruçar mais demoradamente sobre o assunto, passarei, pois, a referir alguns dos resultados do nosso trabalho em áreas mais específicas.

\section{Novas propostas de leitura (com duas breves notas sobre os manuscritos)}

A edição dos mais de 1700 textos que integram a presente base de dados foi, como se compreende, a tarefa mais longa, difícil e complexa deste projecto. Não tendo partido do zero, mas apoiando-nos na já longa tradição filológica sobre a matéria, procurámos ter em conta, na leitura que fizemos dos manuscritos, não só as leituras dos grandes editores clássicos, como Oskar Nobiling, Henry Lang, Carolina Michaëlis ou Rodrigues Lapa, mas também as leituras mais recentes, seja por género (como é o caso das 500 Cantigas d'Amigo de Rip Cohen ${ }^{1}$ ), sejam as propostas nas edições monográficas de trovadores e jograis que nas últimas décadas têm vindo a ser publicadas com regularidade, sobretudo na Galiza e em Itália (sempre que a elas tivemos acesso). Sendo certo, no entanto, que o mero bom senso dirá que, nesta matérias, a antiguidade não é sintoma de menor inteligência ou argúcia, não quereria deixar de referir aqui explicitamente a ajuda preciosa que constituiu, já numa fase adiantada do nosso trabalho, a muito recente série de traduções de textos fundamentais da filologia portuguesa, a partir dos originais alemães de difícil acesso, traduções em boa hora levadas a cabo sob a coordenação de Yara Frateschi Vieira. Tanto nos estudos de Nobiling ${ }^{2}$ ou de $\mathrm{Lang}^{3}$, como nas muito citadas mas, até recentemente, pouco lidas Randglossen de D. Carolina ${ }^{4}$, os textos agora traduzidos, há abundante material relativo aos mais diversos aspectos da poesia trovadoresca, material imprescindível quer à sua edição, quer ao seu estudo. Sendo o Alemão uma língua que poucos dominam, a oportuna iniciativa da Prof ${ }^{\mathrm{a}}$ Yara Frateschi merece, pois, o mais justo reconhecimento por parte de todos os que trabalham neste campo.

\footnotetext{
${ }^{1}$ Campo das Letras, Porto, 2003

2 As cantigas de D. Joan Garcia de Guilhade e estudos dispersos, Editora da Universidade Federal Fluminense, Niterói, 2010

${ }^{3}$ Cancioneiro d'el rei Dom Denis e Estudos dispersos, Editora da Universidade Federal Fluminense, Niterói, 2010

${ }^{4}$ Glosas Marginais ao Cancioneiro Medieval Português, Acta Universitatis Conimbrigensis, Coimbra, 2004
} 
Pese embora todo o importante trabalho filológico, antigo ou recente, já efectuado sobre este corpus, o certo é que, por questões que se prendem com as mais variadas deficiências da tradição manuscrita (textos incompletos ou visivelmente deturpados, variantes, etc.), muitas das cantigas trovadorescas continuam a levantar grandes problemas de edição. Procurámos resolvê-los da forma que nos pareceu mais adequada, sobretudo tendo em conta os objectivos desta edição electrónica, já antes referidos. Sendo impossível, como já antes referi, enumerar detalhadamente todos os passos em que divergimos de leituras anteriores (sobretudo em passos em que essas leituras eram já conjecturais), ou todas as pequenas ou médias alterações introduzidas nesta nossa edição ${ }^{5}$, chamarei a atenção apenas, neste ponto, para um punhado de novas propostas de leitura que nela avançamos, com mais ou menos certezas, mas sempre no sentido de abrir a discussão sobre estes passos problemáticos do corpus trovadoresco. Serão referências relativamente sucintas as que se seguem, já que o leitor destas notas poderá seguir as hiperligações indicadas e analisar mais demoradamente a questão (e consultar os manuscritos, se assim o entender ${ }^{6}$ ).

Começarei por referir uma das mais interessantes mas também mais complicadas cantigas de todo o corpus, a composição "Alá u nasq la Torona”, de D. Garcia Mendes d'Eixo, de resto também uma das composições mais antigas. Trata-se de uma cantiga que, em termos de edição, reúne em si duas barreiras difíceis de ultrapassar: o facto de nos ter sido transmitida de forma altamente deturpada pelo manuscrito $(\mathrm{B}$, o único que a transmite), e o facto de visivelmente se relacionar com um contexto político específico, cujos contornos continuam a ser para nós assaz nebulosos (aspecto que retomarei no ponto 6). Atendendo a estas duas condicionantes, e se nenhum outro dado factual novo vier entretanto alterar a situação, por certo que dificilmente poderemos chegar a uma reconstrução mais ou menos fiel do texto original. Mas poderemos, eventualmente, ir melhorando a sua edição. Editada por mim num anterior trabalho ${ }^{7}$, ela é agora apresentada na BD numa nova proposta de leitura, que procura seguir as pistas

\footnotetext{
${ }^{5}$ Para uma melhor clarificação deste ponto, remeto para os critérios de edição e anotação, disponíveis no site (no menu "Projeto Littera").

${ }^{6}$ Por este motivo, também não indicarei neste texto a localização das cantigas nos manuscritos, já que esta informação consta da página de cada cantiga.

7 Cantigas de escárnio e maldizer dos trovadores e jograis galego-portugueses, Lisboa, Editorial Estampa, 2002.
} 
resultantes da investigação, alheia e própria, entretanto efectuada. Podendo essa proposta ser consultada na base, não me irei deter especialmente sobre ela. Gostaria apenas de salientar aqui um outro dado resultante da nossa investigação e que me parece interessante, relacionado com a língua em que está escrita a composição. Trata-se, na verdade, como desde sempre foi sinalizado, de uma cantiga (da única cantiga deste corpus) que visivelmente não utiliza o galego-português, mas antes uma língua ou dialecto provençal, e que Carolina Michaëlis supôs ser limosino. Propomos, na base de dados, que se tratará antes do gascão. De facto, a cantiga vem acompanhada, no cancioneiro, de uma rubrica explicativa muitíssimo deturpada (cuja edição também alterámos), mas onde é claro o nome de Rui d'Espanha como o destinatário da mesma. Ora, num artigo muito recente, Souto Cabo, procurando identificar esta personagem, avança que o apelido Espanha foi usado por uma linhagem de origem catalã que parece ter tido como núcleo territorial o Vale de Aran, nos Pirinéus e na fronteira francesa, mas que, em meados do século XIII, se fixou na Galiza ${ }^{8}$. Procurando essencialmente estabelecer a ligação dos Espanha (e especificamente de Rui d'Espanha) com a Galiza, Souto Cabo não se detém especialmente nas origens geográficas da linhagem. Mas o facto é que o Vale de Aran é um território onde se falava um dialecto específico do occitânico, próximo do gascão (e de que resulta o aranês, ainda hoje uma das línguas oficiais do território, juntamente com o castelhano e o catalão). Assim sendo, pensamos ser muito possível que a composição de D. Garcia de Sousa tenha sido escrita exactamente neste dialecto. Porque se trata, como dissemos, de uma das mais antigas cantigas que nos foram transmitidas, este dado poderá constituir mais uma achega nas tão discutidas quanto nebulosas origens da poesia galego-portuguesa. Não sendo o meu propósito retomar essa questão aqui, limito-me a chamar a atenção para esta nova sugestão, deixando a discussão mais alargada das suas implicações para um outro momento.

Uma referência breve à edição que propomos para a famosa cantiga de amigo de Mendinho, “Sedia-m'eu na ermida de Sam Simion”, cujo problemático refrão tem feito correr rios de tinta. O problema, recordo, reside nos três ou quatro caracteres que, nos

\footnotetext{
8 "O eco das primeiras vozes", Voz, Actas do VIII Colóquio Internacional da Secção Portuguesa da AHLM, Novembro de 2010, org. Elisa Maria Oliveira Gomes da Torre, UTAD, Vila Real, 2011, p. 30.
}

Medievalista online $\mathrm{N}^{0} 12 \mid$ Julho - Dezembro $2012 \odot$ IEM - Instituto de Estudos Medievais 9 www2.fcsh.unl.pt/iem/medievalista 
manuscritos, se seguem à expressão, bem legível, "Eu atendendo meu amig", e que poderíamos precariamente transcrever como $\langle e \bar{u} a>$. Desde sempre entendida como a indicação da repetição da frase anterior (no que seria um refrão duplo "Eu atendendo meu amigo/ eu atendendo meu amigo", forma que, até recentemente, surgia em todas as edições da cantiga), esta curta sequência e o conjunto do refrão foram, há uns anos, objecto de minucioso estudo por parte de Giuseppe Tavani ${ }^{9}$, que, contestando a leitura tradicional, propôs que o refrão da cantiga seria "Eu atendendo meu amigo. E verrá?". Muito embora esta proposta do ilustre especialista italiano não tenha acolhido a unanimidade entre a comunidade científica que se dedica a estas matérias, é ela que tem sido adoptada na maioria das edições mais recentes de Mendinho. Pela nossa parte, tendo igualmente dúvidas, e até porque a questão, sendo polémica, não é de fácil resolução, optámos por uma leitura minimalista deste passo ('Eu atendendo meu amig', eu a[tendendo]"), leitura que procura evitar intervenções de fundo no testemunho pouco claro dos manuscritos e que é semanticamente mais neutra. Como todas as outras que têm vindo a ser sugeridas, também a nossa proposta é, no entanto, meramente conjectural, já que, mais uma vez, se nenhum outro dado vier acrescentar-se aos que possuímos, dificilmente se poderá chegar a uma reconstrução indiscutível do original.

A mesma incerteza rodeia a cantiga de Afonso Mendes de Besteiros, "O $\underline{O}$ arraes de Roi Garcia", cuja edição mais comum (a proposta por Rodrigues Lapa) também sofreu ligeiras alterações. Desde logo por termos decidido manter, no verso final do refrão, o verbo que claramente se lê no manuscrito, enlinhoo, em lugar de seguir a sugestão de Lapa, que o corrige para "enseinou-o", partindo do pressuposto que se trataria do antónimo do verbo usado no primeiro verso do refrão "desseinou-o". Muito embora seja esta, sem dúvida, uma correcção semanticamente interessante ${ }^{10}$, a repetida clareza do manuscrito neste passo (a forma enlinhoo repete-se três vezes de forma integral e uma vez de forma parcial) levou-nos a optar, também aqui, por uma maior prudência no que toca a intervenções de fundo na sua edição. De resto, e embora não se trate já de uma intervenção editorial, discutimos também, na nota geral a esta cantiga de Afonso

9 Publicado em 1988 na revista Grial, n99, é retomado em "Aínda sobre Martín Codax e Mendinho", Actas do Congreso O Mar das Cantigas (Illa de San Simón, 21-23 de maio de 1998), Santiago de Compostela, 1999, p. 43-57.

${ }^{10}$ E que adoptei na minha edição anterior, já referida. 
Mendes, e em diálogo com um excelente estudo que Resende de Oliveira publicou sobre a matéria ${ }^{11}$, um novo sentido possível para o termo "arrais", em jeito de novo contributo para a clarificação desta complicada cantiga (que retomaremos igualmente no ponto 6).

Termino este ponto com a indicação muito breve de algumas outras cantigas em que propomos pequenas alterações editoriais, consultáveis na base: "Ora faz host'o senhor de Navarra", de João Soares de Paiva (neste caso, seguindo de perto a leitura de José Carlos Miranda para a primeira estrofe ${ }^{12}$ ); a conhecida cantiga de Fernando Esquio "Que adubastes, amigo, alá em Lug'u andastes", onde lemos de maneira diferente do habitual o seu conhecido refrão; a cantiga de João Servando "Comerom [os] infanções, em outro dia", onde também propomos uma nova leitura para o refrão; as cantigas de Afonso X “Á daiam de Cález eu achei” (2ª estrofe), “Com”eu em dia de Páscoa queria bem comer" (neste caso, a nova proposta de edição resulta do trabalho do Manuel Pedro Ferreira sobre a cantiga, devido às referências musicais nela presentes), "Dom Gonçalo, pois queredes ir daqui pera Sevilha" (especialmente o complicado v. 12), "Med'hei do pertigueiro que tem Deça" (neste caso, chamando a atenção para a nota de leitura ao v. 4, onde se sugere uma leitura alternativa para o complicado refrão), sem esquecer as duas Cantigas de Santa Maria presentes nos Cancioneiros (uma delas em lição única), "Falar quer'eu da senhor bem cousida" e "Deus te salve, Gloriosa" (sendo que em ambas o trabalho do Manuel Pedro Ferreira foi igualmente central); a cantiga de Rui Fernandes de Santiago "Ora nom dev'eu preçar parecer” (onde introduzimos um segundo verso, incompleto, no refrão, com referência a Sevilha, sugestão já avançada, mas não adoptada, por Rip Cohen ${ }^{13}$ ); a cantiga de Airas Nunes "O $\underline{\mathrm{O} \text { meu senhor bispo, na }}$

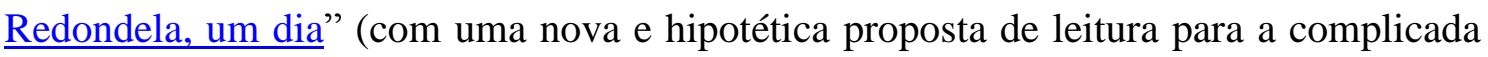
$2^{\mathrm{a}}$ estrofe); a muito estropiada cantiga de João Servando "Dom Domingo Caorinha" (com uma nova proposta de leitura para a $3^{\mathrm{a}}$ estrofe); a cantiga de Estêvão da Guarda, "Pois a todos avorrece" (com uma leitura diferente do $1^{\circ}$ verso do refrão e um novo sentido para o termo "pedrolo" que nele surge); isto sem esquecer a quase totalidade das

\footnotetext{
11 "Rui Garcia de Paiva no escárnio Galego-Português", Revista Portuguesa de História, t. XXXVI, vol. I, 2002-2003, pp. 285-295

12 Aurs mesxlatz ab argen. Sobre a primeira geração de trovadores galego-portugueses, Edições Guarecer, Porto, 2004, pp. 22-32

${ }^{13}$ Ob. cit., p. 332
} 
cantigas espúrias presentes nos apógrafos italianos, algumas das quais, por se situarem numa zona pouco frequentada, em geral, pelos especialistas, editamos praticamente de raiz.

Uma palavra também para a nova edição que fazemos da "Arte de Trovar", o pequeno tratado de poética trovadoresca que abre o Cancioneiro da Biblioteca Nacional. Tratando-se, como é sabido, de um texto muito problemático (já que, para além de se apresentar truncado no seu início, apresenta igualmente muitos passos lacunares e outros de muito difícil leitura), a sua edição está longe de ser fácil. Procurando ter em conta as duas principais edições anteriores de que foi objecto, a de Jean Marie D’Heur e a de Giuseppe Tavani ${ }^{14}$, arriscámos, mesmo assim, alterações significativas às leituras que estes dois especialistas tinham proposto para alguns passos. As referidas dificuldades do manuscrito, no entanto, não são de molde a garantir que tenhamos efectivamente melhorado a sua edição.

Esquecendo, muito provavelmente, outras intervenções editoriais que apresentamos na $\mathrm{BD}$, o desejo da equipa é que tanto as novas propostas de leitura acima explicitamente referidas como todas as outras possam ser objecto de discussão pela comunidade científica que se debruça sobre as cantigas, de forma a podermos ir gradualmente melhorando a edição deste tão aliciante quanto complexo corpus trovadoresco.

De resto, sobre a área mais geral dos manuscritos, farei ainda duas breves considerações. A primeira, para referir uma das tarefas nunca efectivamente realizadas, mas de cuja utilidade nenhum especialista certamente terá dúvidas, e que diz respeito à necessidade de se proceder, num futuro mais ou menos próximo, a uma análise cuidada da iconografia do Cancioneiro da Ajuda. Refiro-me, bem entendido, às iluminuras (que disponibilizamos numa página independente, com uma muito breve descrição do Manuel Pedro Ferreira), mas também às iniciais trabalhadas (algumas com figuras antropomórficas, como é o caso da discutida cantiga A 62, "Pois nom hei de D. Elvira", cantiga a que regressarei adiante), ou mesmo a alguns outros "objectos" que comparecem nos fólios deste códice, como é o caso da interessante e estranha imagem desenhada no final da cantiga A 252, imagem que, se não estou em erro, não mereceu

\footnotetext{
${ }^{14}$ Ver a página Bibliografia, para as referências.
} 
ainda qualquer referência. Podendo representar um instrumento de sopro, com embocadura e pavilhão em forma de cabeça de animal e uma espécie de "notas" a formar um padrão decorativo, espera ainda, de facto, uma atenção mais demorada (que incluiria, necessariamente, as razões da sua inserção naquele lugar). Sendo certo que também na BD esta imagem é apenas meramente assinalada, não queria deixar por isso de sinalizar a questão aqui.

A outra referência diz respeito aos apógrafos italianos, onde há igualmente pormenores curiosos, entre os quais saliento, de momento, apenas o facto de a cantiga de Pero Guterres "Todos dizem que Deus nunca pecou”, uma das sete cantigas satíricas que, no nosso corpus, são dirigidas "contra" Deus, se apresentar claramente riscada no Cancioneiro da Vaticana ( $\underline{\mathrm{V} \text { 510)}}$, o que, sendo caso único neste manuscrito, e não parecendo justificar-se pela detecção posterior de qualquer erro de cópia (a cantiga está correctamente inserida no seu lugar), também não parece ficar a dever-se ao acaso, mas antes, plausivelmente, ao próprio tema da composição. Como aquilo que sabemos em relação à história dos manuscritos galego-portugueses é notoriamente pouco, este provável vestígio concreto de uma leitura posterior do Cancioneiro da Vaticana merece, creio, ser destacado ${ }^{15}$.

Por fim, e exactamente porque pouco sabemos destas matérias, uma referência ao quadro geral comparativo das cantigas e dos cancioneiros em que são transcritas, recurso que julgámos útil incluir na $\mathrm{BD}$. Elaborado gradualmente ao longo do nosso trabalho, e finalizado tendo em conta os estudos efectuados pelas especialistas que se debruçaram sobre os três principais códices (Anna Ferrari para os apógrafos italianos e Maria Ana Ramos para o códice da Ajuda), não quisemos deixar de o disponibilizar na BD. Trata-se, de qualquer forma, de um recurso com um claro estatuto de "rascunho" (até mesmo na sua forma PDF), e que necessitará certamente de desenvolvimento posterior.

\footnotetext{
${ }^{15}$ Embora esta informação já esteja no site, aproveito para assinalar também aqui que, neste momento, se encontra disponível para consulta, no IEM, um CD com novas fotografias de alta resolução do Cancioneiro da Vaticana. Feitas especialmente para o Projecto, elas não podem ser disponibilizadas directamente online, nos termos do protocolo que fizemos com as autoridades da Biblioteca Vaticana, podendo, no entanto, ser livremente consultadas no Instituto.
} 


\section{Citações internas e relações intertextuais}

Uma das vantagens de se trabalhar com a totalidade do corpus trovadoresco profano, e, para mais, de se trabalhar com a sua edição electrónica, é a possibilidade acrescida de se detectarem relações cruzadas entre textos, ou seja, de se tornarem bem mais evidentes as ligações que muitas cantigas estabelecem entre si. A existência destas ligações internas não é, bem entendido, um facto novo, e desde há muito que a questão tem sido abordada nas suas diversas facetas, que podem ir do estudo de cantigas iguais ou semelhantes atribuídas pelos manuscritos a dois autores (como é o caso, entre outros, da célebre bailia "das avelaneiras", de que temos duas versões, uma de Airas Nunes e outra de João Zorro), ao estudo das cantigas de seguir, uma das modalidades trovadorescas mais demoradamente explicadas pela "Arte de Trovar", mas às quais, creio, ainda não foi dada a atenção que merecem (e que esta $\mathrm{BD}$, de momento, também não lhes dá, questão que abordarei no último ponto destas notas). Igualmente sinalizadas têm sido algumas citações internas, ou seja, cantigas que retomam versos de uma outra cantiga, seja de forma exacta, seja com ligeiras variações. O processo ocorre no interior da obra de um mesmo trovador, com cantigas de amor e de amigo citando-se mutuamente, por exemplo (sendo o caso mais conhecido e notável o de João Garcia de Guilhade), ou desenvolve-se a partir de cantigas alheias, neste caso assumindo frequentemente um valor satírico. A questão parece-me das mais interessantes, até por remeter novamente para a subtileza ou para a dimensão "minimalista" da arte trovadoresca, já antes referida. Porque, na verdade, estas citações são sempre funcionais, ou seja, fornecem um sentido acrescentado aos textos, no caso, um sentido que, também já na época, seria apenas eventualmente descodificado por um grupo reduzido de ouvintes, os do círculo restrito do autor da cantiga ou aqueles que possuíssem um conhecimento mais ou menos alargado do repertório trovadoresco. Seja como for, no que toca a citações alheias, e para além dos casos há mais ou menos tempo sinalizados, enunciarei aqui alguns outros a que fazemos referência na BD e que, a meu conhecimento, ou são inéditos, ou pouca atenção têm merecido.

Começarei, de resto, com um dos casos já há muito conhecidos, o de Airas Nunes, trovador muito dado a estes jogos intertextuais, nomeadamente a partir de composições 
provençais (questão que não abordarei aqui), mas também a partir de composições galego-portuguesas, como acontece na pastorela "Oí hoj'eu ũa pastor cantar". Trata-se, na verdade, de uma composição cujas quatro estrofes terminam com citações de cantigas de amigo alheias, duas delas, bem localizadas (uma de Nuno Fernandes Torneol, na $3^{\mathrm{a}}$ estrofe, e outra de João Zorro na $4^{\mathrm{a}}$ ), e outras duas (ou três) difíceis de localizar (as utilizadas na $1^{\mathrm{a}}$ e na $2^{\mathrm{a}}$ estrofes, e talvez a citação final da $4^{\mathrm{a}}$ estrofe). Não dispomos, infelizmente, da música de nenhuma destas composições, o que seria, obviamente do maior interesse, até pelas variações métricas presentes nesses diferentes segmentos que Airas Nunes introduz na sua pastorela como refrão. Mas, tal como Tavani ${ }^{16}$, adoptámos, no refrão da $4^{\mathrm{a}}$ estrofe, por exemplo, a disposição gráfica que os versos de João Zorro apresentam na composição do próprio (área lateral em que estas citações internas se mostram igualmente úteis). De qualquer forma, o que Tavani não refere, e para isso chamarei a atenção aqui, é o facto de, no caso do refrão da $2^{\mathrm{a}}$ estrofe, um dos que não corresponde a nenhuma cantiga de amigo conhecida, o verso final (e d'amores hei mal) ser exactamente idêntico ao refrão de uma cantiga satírica de Rui Pais de Ribela, "Mala ventura me venha". Não se tratando, neste caso de Ribela, de uma cantiga de amigo, creio que o mais plausível é ambos os trovadores citarem uma composição alheia, cujo refrão completo seria o que surge em Airas Nunes. A ser assim, essa fonte comum, podendo ser uma cantiga de amigo (perdida) de um outro trovador, poderia também ser uma cantiga da tradição oral popular (como eventualmente teria sido o caso, e cito a opinião de Rodrigues Lapa ${ }^{17}$, da bailia "das avelaneiras", da qual temos as já referidas duas versões, uma de Airas Nunes e outra de João Zorro). Partindo desta hipótese de uma fonte tradicional comum a Airas Nunes e a Rui Pais de Ribela para o refrão "d'amores hei mal", não seria impossível pensarmos então que, na verdade, na sua pastorela, Airas Nunes citaria exclusivamente cantigas do repertório popular, duas das quais teriam sido igualmente utilizadas por Nuno Fernandes Torneol e João Zorro para a composição das suas próprias cantigas de amigo. No seu prefácio à edição galega de A poesia de Airas Nunes (a edição que cito em nota), Tavani, comentando a opinião de Rodrigues Lapa acima referida, mostra-se céptico em relação

\footnotetext{
${ }^{16}$ A poesia de Airas Nunes, Editorial Galáxia, Vigo, 1992 (para a edição galega)

17 Lapa, Manuel Rodrigues Recensão a Tavani, Giuseppe, Le poesie di Ayras Nunez, Ugo-Merendi Editore, Milão, 1964, in Boletim de Filologia, Tomo XXII, Centro de Estudos Filológicos, Lisboa, 19641973.
} 
à ideia de que poderia ter havido "um préstamo simultâneo e autónomo de materiais" de temas populares por parte de Airas Nunes e dos trovadores cujas cantigas parecem ser citadas na sua pastorela (Torneol e Zorro, os autores que Tavani refere). Penso que a sinalização que agora fazemos da coincidência entre o último verso do refrão da segunda estrofe da composição e o refrão da cantiga satírica de Rui Pais de Ribela poderá eventualmente relançar o debate.

Ainda que menos discutido, um outro autor onde é possível detectar com relativa frequência este jogo intertextual é Afonso X. O caso mais flagrante é o de uma das suas três únicas cantigas de amor conservadas, "Pois que m'hei ora d'alongar", cantiga de mestria cujas três estrofes terminam com citações de refrães de cantigas de amor alheias, a primeira e a segunda citando textualmente duas cantigas de João Soares Coelho, a terceira citando, com variantes, uma cantiga de Pero d'Armea (ou mesmo de Pero Garcia Burgalês, já que também numa cantiga deste último encontramos uma variação do mesmo segmento). Como dizemos na BD (na primeira das notas a esta cantiga de Afonso X), é muito possível que estas citações não fossem um mero jogo de virtuosismo técnico, mas tivessem um qualquer sentido específico, hoje difícil de entender cabalmente. Na verdade, pensamos que, para além do facto de esses versos finais das estrofes introduzirem o que parece ser um tom jocoso no universo fechado do canto de amor, a dupla citação de João Soares Coelho não será certamente fortuita. Acrescente-se, de resto, que as duas cantigas de amor de João Soares citadas por Afonso $\mathrm{X}$ não parecem ser tematicamente alheias a esta problemática, já que a primeira tem um incipit muito significativo, "Pero m'eu hei amigos, nom hei ni um amigo", e a segunda ("Deus, que mi hoj'aguisou de vos veeer") contém uma muito curiosa, se bem que críptica, referência a uma "filha de rei" (v.13 e sgs.). Já a citação da cantiga de Pero d'Armea na terceira estrofe parece mais difícil explicar, visto tratar-se de uma cantiga de amor que aparentemente se limita a seguir os modelos canónicos do género. Seja como for, e partindo dos dados expostos, caberia talvez perguntar: não poderia a cantiga de Afonso X relacionar-se ainda, de alguma forma, com o célebre "ciclo da ama", exactamente desencadeado por João Soares Coelho, e que tanto agitou a corte alfonsina? Não cabe no espaço destas curtas notas discutir o assunto, mas será eventualmente uma pista a seguir (regressarei brevemente à "questão da ama" no ponto 6, mas aí sem incluir este aspecto). 
De Afonso X, e de entre outros casos já conhecidos, referirei ainda a composição "Pero da Pont'há feito gram pecado", cantiga satírica onde o rei brinca com um desaguisado, pessoal e artístico, entre o dito Pero da Ponte e Afonso Anes do Cotom. Como avançamos na $\mathrm{BD}$, o facto de a cantiga insistir, nas duas primeiras estrofes, no verbo "lazerar", sempre aplicado a Cotom ("quant'el lazerado/houve" e "quant'el foi lazerar”) poderá ser um indício de que o rei estará, na verdade, a citar irónica e jocosamente a única cantiga de amor de Cotom (a única que nos chegou), cujo incipit é exactamente "A gram dereito lazerei". A questão extravasa, de resto, a mera detecção de uma relação intertextual, já que, tendo em conta as indicações contraditórias dos apógrafos italianos, a autoria desta última cantiga não é absolutamente segura (V atribui-a a Airas Engeitado, enquanto B e C a atribuem a Cotom). A hipótese que avançamos (e que discutimos um pouco melhor na nota geral à cantiga) seria, pois, mais um elemento que confirmaria a sua mais provável atribuição a Cotom.

Referiremos, por último, dois outros casos igualmente pouco conhecidos neste campo das relações intertextuais. Um deles é o protagonizado pelas cantigas "Já lhi nunca pediram", de Afonso Mendes de Besteiros (uma das conhecidas cantigas contra os "alcaides traidores"), e "Ũa dona foi de pram", de Gonçalo Anes do Vinhal, cantigas que partilham o refrão "com mínguas que havia" (embora o refrão da primeira seja apenas este verso, enquanto que o da segunda tem um outro verso suplementar). Tratando-se de duas cantigas satíricas, o sentido desta partilha não é tão fácil de situar como nos casos em que uma cantiga satírica cita uma cantiga de amor ou de amigo. Mas ela não será certamente fortuita. A cantiga de Vinhal, centrando-se nos favores que uma dona receberia da Ordem do Hospital, é, de facto, uma crítica indirecta a essa Ordem. Teria Afonso Mendes de Besteiros sido um dos seus membros? Não disponho de qualquer dado nesse sentido, mas poderá ser eventualmente uma pista a seguir.

O outro caso é ainda mais problemático. Trata-se de três versos exactamente iguais que surgem em duas cantigas de amor bastante diferentes, uma de João Garcia de Guilhade, "Estes meus olhos nunca perderám", e outra de Rodrigo Anes de Vasconcelos, “Aquestas coitas que de sofrer hei". Os referidos versos são "Guisado têm de nunca perder/ meus olhos coita e meu coraçom,/ e estas coitas, senhor, minhas som" (que, na cantiga de Guilhade, correspondem ao início da segunda estrofe, e, na de Rodrigo Anes, ao início da terceira). O problema é tanto mais complicado quanto a cantiga de Rodrigo 
Anes é assaz obscura, não sendo mesmo absolutamente claro se se trata efectivamente de uma cantiga de amor ou de uma cantiga de amigo (se estamos perante uma voz masculina ou feminina). $\mathrm{O}$ facto de partilhar estes três versos com a cantiga de amor de Guilhade é mais um elemento a juntar à estranheza geral da composição. Podendo, neste caso, tratar-se de uma simples deficiência da tradição manuscrita (o copista teria copiado inadvertidamente versos errados numa das composições), também pode tratarse de uma verdadeira relação intertextual, que anoto, mas para a qual não avanço qualquer explicação.

\section{Notas biográficas de autores e questões de autoria}

Desde Carolina Michaëlis, pelo menos, que uma das tarefas mais importantes mas também mais complicadas no que toca à poesia trovadoresca galego-portuguesa tem sido a de identificar, tanto quanto possível, os seus autores. Na verdade, se em relação a alguns deles (monarcas ou ricos-homens de reconhecida notoriedade) os dados biográficos de que dispomos são relativamente abundantes, em relação à larga maioria dos nomes que comparecem nos apógrafos italianos ou na longa lista de autores elaborada por Colocci (a Tavola Colocciana) esses dados são escassos ou mesmo totalmente inexistentes (o caso mais evidente sendo, como se compreende, o dos jograis). Atendendo às dificuldades da tarefa, mais notável se torna o trabalho de D. Carolina nesta matéria, trabalho do qual resultaram os numerosos e, ainda hoje, valiosos dados biográficos que expõe no volume II do Cancioneiro da Ajuda e que representam, no seu conjunto, uma parte substancial desse volume. A extensa erudição de D. Carolina e o rigor que pôs no seu trabalho fazem dele uma fonte imprescindível, e mesmo, durante largos anos, a única fonte disponível sobre a vida dos trovadores e jograis. Em termos gerais, só a partir de inícios dos anos 1990 a situação conheceu um desenvolvimento significativo, muito particularmente com a publicação da tese de doutoramento de António Resende de Oliveira, Depois do espectáculo trovadoresco. A estrutura dos cancioneiros peninsulares e as recolhas dos séculos XIII e $\mathrm{XIV}^{18}$, trabalho que, entre outros méritos, incluía, nas suas páginas finais, uma preciosa resenha das

\footnotetext{
${ }^{18}$ Edições Colibri, Lisboa, 1994.
} 
biografias de todos os autores presentes nos cancioneiros, e na qual o autor não só fazia uma revisão crítica dos dados de D. Carolina, como avançava inúmeros dados novos relativos a um vasto conjunto de autores. A este e aos posteriores trabalhos de Resende de Oliveira sobre a matéria, estudos hoje em dia incontornáveis, vieram juntar-se, em anos mais recentes, um conjunto de novos trabalhos que, geralmente em diálogo com Resende de Oliveira, têm vindo a completar ou mesmo a alterar significativamente o que sabíamos sobre as biografias dos trovadores e dos jograis galego-portugueses. Entre esses trabalhos destacarei, pela sua pertinência e pelo seu carácter genérico, os de Ron Fernández ${ }^{19}$, de José António Souto Cabo ou de Vincenç Beltran ${ }^{20}$.

As breves notas biográficas sobre os trovadores e jograis que disponibilizamos na BD muito devem a todos estes trabalhos, cujos dados (nem sempre coincidentes, diga-se) procurámos harmoniosamente integrar. A título pessoal, aproveito, aliás, para expressar publicamente aqui os meus agradecimentos ao António Resende de Oliveira pela disponibilidade (e a paciência) sempre demonstradas no que toca às numerosas dúvidas que informalmente lhe fui colocando. O meu agradecimento é extensivo ao José António Souto Cabo, particularmente pela pronta disponibilização de alguns trabalhos seus, inéditos à data da apresentação pública da BD. Mas para além destes incontornáveis contributos, as notas biográficas procuraram ainda ter em conta uma série de outros dados, quer os directamente retirados os Livros de Linhagens ou de algumas outras fontes, quer os provenientes de edições monográficas e de estudos diversos, e que não irei enumerar detalhadamente aqui, até porque essa origem é sempre indicada nas notas bibliográficas das páginas respectivas. Não posso, no entanto, deixar de referir explicitamente a ajuda preciosa que constituiu o importante trabalho de José Augusto Pizarro, Linhagens Medievais Portuguesas: genealogias e estratégias, para mais em tão boa hora disponibilizado online pela Universidade do Porto (como tese de doutoramento que foi $)^{21}$. Embora se trate, como o seu nome indica, de um estudo geral sobre a nobreza portuguesa medieval, e não, obviamente, sobre os trovadores, nele nos

\footnotetext{
19 "Carolina Michaëlis e os trobadores representados no Cancioneiro da Ajuda", in Carolina Michaëlis e o Cancioneira da Ajuda hoxe, Xunta de Galicia, Santiago de Compostela, 2005

${ }^{20}$ No que toca aos trabalhos de Souto Cabo e também de Vincenç Beltran, que são múltiplos, consulte-se a página da Bibliografia incluída na BD.

${ }^{21}$ Centro de Estudos de Genealogia, Heráldica e História da Família da Universidade Moderna, Porto, 1999. Na página da Bibliografia do site indicamos o endereço electrónico onde a obra pode ser consultada (em pdf. pesquisável).
} 
baseámos para introduzir algumas informações suplementares nas biografias de alguns autores, informações essas que, por mais recentes, ainda não constavam dos trabalhos específicos dos investigadores anteriormente referidos. Tratando-se, em geral, de pequenos dados, eles não deixam de ser importantes, já que, mesmo no caso dos autores sobre os quais não há dúvidas sobre a sua linhagem ou sobre os aspectos gerais da sua biografia, conhecemos por vezes bastante mal o seu percurso concreto, elemento em muitos casos fundamental para a interpretação, datação, ou mesmo autoria das cantigas.

As notas biográficas disponibilizadas na BD têm, pois, um carácter compósito, nalguns momentos procurando avançar igualmente novas pistas e novas hipóteses, suscitadas tanto pela análise cruzada das diferentes propostas dos especialistas, como pela nossa própria pesquisa. Sendo impossível, também nesta matéria, apontar minuciosamente todas elas, chamarei a atenção, desde já, e de forma mais global, para as reformulações, por vezes muito significativas, que na BD sofreram as biografias de quase todos os autores das chamadas primeira e segunda gerações, reformulações em grande parte apoiadas nas muito recentes investigações de Souto Cabo. Os casos mais em evidência serão eventualmente os de Fernão Pais de Tamalancos (Fernão Pais Capelo), de D.

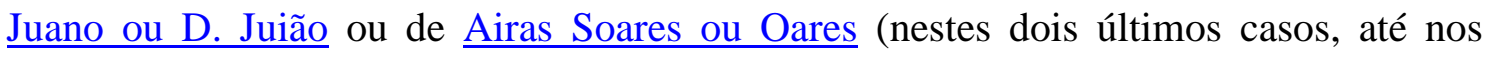
nomes há alteração, embora mantenhamos ainda activos os nomes tradicionais). Mas em quase todos os restantes autores mais recuados há dados novos, eventualmente a necessitar de confirmação e discussão mais detalhadas. Aguardando exactamente que essa discussão se processe, acrescente-se que, do impressionante número de dados factuais novos e novas hipóteses avançadas por Souto Cabo nos seus últimos artigos, nem todos (ou, sobretudo, nem todas essas hipóteses) integram efectivamente a BD. Estou certa, de qualquer forma, que estas notas biográficas, até por a sua matéria se ligar muito estreitamente com o complicado problema das origens da poesia galegoportuguesa, serão aquelas que mais probabilidades têm de vir a sofrer modificações a curto ou a médio prazo.

Feita esta referência de conjunto às primeiras gerações, chamarei ainda a atenção em seguida, de forma muito breve, para um conjunto de outros autores em cujas biografias incluímos dados que poderão suscitar igualmente alguma discussão. 
Começarei por Lopo Lias, trovador cuja biografia está longe de ser pacífica, já que o arco cronológico que lhe tem vindo a ser atribuído varia entre as primeiras décadas (Souto $\mathrm{Cabo}^{22}$ ) e os finais do século XIII e inícios de XIV (Resende de Oliveira). Sendo as razões de um e de outro brevemente resumidas na nota biográfica do trovador, sobre elas não me irei alongar aqui. Mas o certo é que, como Souto Cabo, consideramos mais plausível que a vida activa de D. Lopo Lias tenha decorrido nas primeira décadas do século XIII, e que tenhamos, pois, de o integrar nas fases iniciais do movimento trovadoresco ibérico. Neste sentido, e tendo em conta a referência a Benavente que é feita na segunda das doze cantigas satíricas que o trovador dirige a uns infanções de Lemos, chamo a atenção ainda para a nova proposta contextual para todo esse ciclo que avançamos na nota geral à primeira das suas cantigas, e que vai exactamente no sentido dessa cronologia mais recuada (regressarei, de qualquer forma, ao assunto no ponto 6). A partir desta cronologia, aliás, recolocamos em cima da mesa uma hipótese de D. Carolina Michaëlis relativa ao trovador Airas Moniz de Asma (a de que poderia ser ele o Airas Moniz referido por D. Lopo Lias numa sua composição), e a que fazemos referência na nota biográfica desse trovador.

Um outro autor de biografia problemática é Pero Garcia de Ambroa. Utilizando a expressão “um outro autor” indicamos, desde já, a opção que tomámos na BD, uma vez que, segundo Resende de Oliveira (numa proposta seguida por outros especialistas), estaríamos face não a um, mas a dois indivíduos: Pero de Ambroa e Pero Garcia de Ambroa. Pelas razões que avançamos na nota biográfica respectiva, e que muito devem aos novos documentos localizados por Souto Cabo aí referidos, não nos parece que seja este o caso. A opção que tomámos está, no entanto, perfeitamente aberta à discussão.

Quanto ao trovador Mem Pais, de biografia muito incerta, propomos, na sua nota biográfica, que se tratará da mesma personagem a quem Afonso $\mathrm{X}$ dirige duas cantigas satíricas. Trata-se, neste caso, de uma proposta que apenas viria confirmar uma das duas hipóteses de identificação já avançadas por Resende de Oliveira, no caso, a de que se trataria do galego Mem Pais de Souto Maior ou de Candarei. De resto, partindo dos

\footnotetext{
${ }^{22}$ E também Vicenç Beltran, ainda que por razões diferentes e menos factuais.
} 
dados avançados por Ron Fernández para a biografia de Nuno Rodriges de Candarei, avançamos ainda a hipótese de Mem Pais poder ser seu tio.

Gostaria também de fazer uma breve referência ao chamado Anónimo de Santarém. Tratando-se de um trovador apenas presente no Cancioneiro da Ajuda (manuscrito onde não constam os nomes dos autores), dificilmente poderemos vir a identificá-lo com um mínimo de segurança. Optando por distingui-lo dos restantes anónimos (que diferenciamos na habitual forma numérica) e por designá-lo pelo nome que geralmente lhe é dado ao correr de textos e estudos, avançamos também, na sua nota biográfica, uma série de sugestões quanto à sua identidade, sugestões que têm, bem entendido, um carácter meramente indicativo, e cuja finalidade é essencialmente a de suscitar o debate e a pesquisa. Também nesta entrada avançamos com uma simples pista para uma eventual identificação da senhora de Santarém, muito provavelmente residente em Alfanje, a quem se dirigem as cantigas do trovador, pista que retirámos de uma referência de José Augusto Pizarro relativa a D. Estêvão Peres de Aboim.

Relacionada com Santarém, discutimos ainda brevemente, no final da sua nota biográfica, uma identificação alternativa para Estêvão Raimondo, que o faria neto do trovador Martim Soares. Não temos quaisquer certezas a este respeito, mas decidimos introduzir essa nova pista, de forma a relançar o debate sobre um autor cuja identificação é problemática (até por desconhecermos o seu nome de família). De resto, e no que toca ao próprio Martim Soares, incluímos na sua nota biográfica uma sugestão de José Augusto Pizarro, que vai no sentido de o ligar à linhagem dos Ribeiro (indicação extensiva ao seu eventual irmão, Garcia Soares). Já no que toca aos dois filhos trovadores de D. Garcia Mendes D’Eixo, Fernão Garcia Esgaravunha e Gonçalo Garcia chamarei a atenção, para além da revisão da data da morte do primeiro (e que vai no sentido de uma sugestão já avançada por Vicenç Beltran), para a possível estadia na Catalunha pelo menos do segundo, ao serviço de D. Pedro Sanches, dado igualmente avançado por Pizarro. Uma sugestão, novamente eventual, para a efectiva ligação de

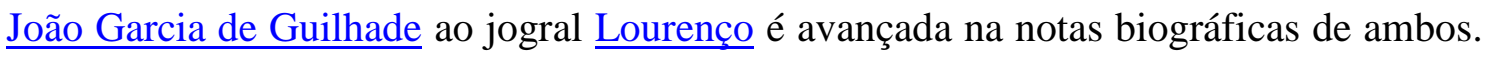
Por último, e dado não pretender alargar excessivamente estas notas, referirei, de forma sucinta, um conjunto de autores em cujas notas biográficas inserimos informação pontual nova ou sugerimos novas pistas, como é o caso de João Lobeira, João Peres de Aboim, o trovador judeu Josepe (que dialoga com Estêvão da Guarda numa tenção), 
Martim Moxa (sobre o qual, novos e contraditórios dados foram avançados recentemente), Pero da Ponte, Pero de Ornelas, Pero Viviães, Rodrigo Anes Redondo, Vasco Praga de Sandim e Vasco Rodrigues de Calvelo.

Sendo a presente BD um projecto que se quer activo, como disse, esperamos, pois, que da discussão das nossas propostas, e também das investigações futuras, possam surgir novos dados que possibilitem a correcção e o alargamento das notas biográficas nela presentemente incluídas.

Um problema que não pode deixar de ter em conta o anterior, embora seja de um âmbito relativamente diferente, é o da atribuição das cantigas ao respectivo autor, questão que num número significativo de casos não é fácil de resolver. O problema prende-se, essencialmente, com dois aspectos: por um lado, com a já referida ausência de nomes de autores no Cancioneiro da Ajuda (o que faz com que apenas as composições desse manuscrito igualmente transcritas nos apógrafos italianos possam ser atribuídas com relativa segurança), e, por outro lado, com as indicações contraditórias de autoria que encontramos nos apógrafos italianos e na Tavola Colocciana. Também neste campo, e ao mesmo tempo que assinalamos sempre a autoria duvidosa de uma cantiga, procurámos integrar na BD informação actualizada, proveniente quer de estudos $\operatorname{alheios}^{23}$, quer das nossas próprias opções (explicadas nas breves notas colocadas à esquerda dos nomes indicados como mais prováveis autores). Neste momento, e no que toca a esta questão, gostaria apenas de chamar brevemente a atenção para três casos particulares, que me parecem dos mais interessantes.

Um deles, é o da cantiga de amor incompleta "Meus olhos, gram coita d'amor", apenas transcrita pelo Cancioneiro da Ajuda, e até recentemente atribuída, sem contestação, a Paio Soares de Taveirós (já que é a última de um conjunto de nove composições que, neste manuscrito, parecem ser de um mesmo autor, sendo que as cinco primeiras são igualmente transcritas por $\mathrm{B}$, e aí atribuídas a Paio Soares). Na BD passamos a considerá-la de autoria duvidosa, e isto tendo em conta a recente e relevante descoberta de Susana Tavares Pedro, que detectou o nome de Pero da Ponte minusculamente

\footnotetext{
${ }^{23}$ E neste aspecto tivemos particularmente em conta, embora nem sempre as seguíssemos, as propostas da equipa da Lírica Profana Galego-Portuguesa (coord. Mercedes Brea, Centro Ramón Piñeiro, Xunta de Galicia, Santiago de Compostela, 1996).
} 
escrito na margem esquerda da inicial de abertura (onde este nome é efectivamente legível, facto que passou despercebido não só a Carolina Michaëlis mas a todos os restantes especialistas que se debruçaram sobre o códice). Embora Susana Pedro já tenha tornado pública a sua descoberta em 2004, ela é ainda relativamente desconhecida (até por não terem ainda sido publicadas as actas do colóquio onde foi apresentada ${ }^{24}$ ), e para ela chamo aqui, pois, a atenção. A questão, como se compreende (sobretudo atendendo ao que antes se disse sobre a ausência de nomes no Cancioneiro da Ajuda), ultrapassa em muito a mera autoria da referida cantiga. Mas tem também implicações nesta matéria, razão pela qual a refiro aqui.

O segundo caso é o da tenção “-_Vós que soedes em corte morar”, uma das cantigas de mais difícil atribuição de todas as que nos chegaram, senão mesmo a mais difícil. Uma vez que expomos os dados do problema na nota geral da composição, não me vou alongar aqui sobre as razões que nos levaram a indicar como seus autores Martim Moxa e um Anónimo. Seguindo, nessa nota, Resende de Oliveira na opinião de que se tratará de uma composição de finais do século XIII ou inícios do XIV, gostaria apenas de acrescentar um outro dado que poderá ter relevância quer na autoria, quer na datação da cantiga (neste último aspecto, eventualmente contrariando até as razões expostas na referida nota), e que diz respeito às formas que surgem na terceira estrofe em posição de rima: dé/ é ( $3^{\text {a }}$ pessoa do pres. do conj. do v. dar, v. 16/ pres. v. ser, v. 18). Assim, e antes de mais, faço notar que esta mesma rima, que é muito rara no nosso corpus, surge efectivamente numa outra cantiga de Martim Moxa ( $2^{\mathrm{a}}$ estrofe), dado este que vem no sentido da plausibilidade de ser ele um dos autores. De resto, seguindo D. Carolina Michaëlis, que na entrada dar do seu Glossário ${ }^{25}$ anota que dé é a forma mais antiga do conjuntivo, sendo que "D. Dinis já rimava dê com quê" (como se poderá verificar em

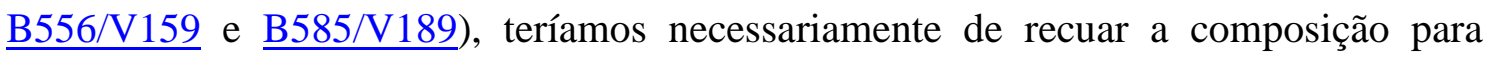
meados do século XIII (tornando plausível que o outro autor fosse eventualmente Lourenço, como indica V). De qualquer forma, será também necessário acrescentar que o único trovador, para além de Martim Moxa, onde encontramos esta mesma rima é João Airas de Santiago (em B953/V541, 2ª estrofe), em princípio um autor mais tardio.

\footnotetext{
24 Consulte-se a Bibliografia da $\mathrm{BD}$, não só para a indicação detalhada, mas também porque nela incluímos o link para o artigo, que se encontra disponível online.

${ }^{25}$ Glossário do Cancioneiro da Ajuda, p. 24, Cancioneiro da Ajuda, vol. I
} 
Fica aqui, no entanto, esta nota suplementar como mais um contributo à resolução da intrincada questão da autoria desta tenção.

O terceiro e último caso diz respeito à opção que tomámos quanto à cantiga Senhor genta, geralmente conhecida como o "Lais de Leonoreta". Trata-se, como se sabe, de uma composição que tem feito correr rios de tinta, uma vez que, surgindo igualmente na versão castelhana da célebre novela de cavalaria Amadis de Gaula, versão essa elaborada, em finais do século XV, por Garcí Rodriguez de Montalvo, a partir de um original medieval hoje perdido, a sua autoria necessariamente se liga com a complexa e muito discutida questão da autoria da própria novela (e da sua língua original). No Cancioneiro da Biblioteca Nacional, único manuscrito que a transmite, a cantiga de Leonoreta é claramente atribuída por Colocci ao trovador João Lobeira, informação que a Tavola Colocciana reitera. De D. Carolina Michaëlis a Rodrigues Lapa, João Lobeira tem sido, pois, indicado como o autor do Amadis primitivo, cuja língua seria assim o galego-português. Como explicamos um pouco melhor na nota geral da cantiga, mais recentemente vários especialistas, tendo em conta a forma algo anómala como a composição se apresenta em B (a primeira estrofe no folio 64, em B 244, as duas seguintes no verso do mesmo folio, seguindo B 246, e sem numeração), defenderam que se trataria, na verdade, não de uma cantiga de João Lobeira, mas de uma composição espúria, ou seja, de uma das várias composições tardias, acrescentadas em época posterior em espaços em branco do manuscrito medieval e copiadas igualmente por Colocci. Se a disposição anómala da composição no manuscrito é indiscutível e torna esta hipótese plausível, também é certo que algumas dúvidas nos parecem ainda subsistir. Na verdade, sendo esta a primeira composição atribuída por Colocci a João Lobeira (que, em B, escreve o seu nome imediatamente antes da primeira estrofe), e não parecendo plausível que, no manuscrito medieval primitivo ao nome do trovador se seguisse um espaço em branco (onde alguém teria inserido posteriormente uma cantiga), só poderemos concluir que, ou Colocci se enganou (e o nome do trovador, no manuscrito que copiava, seguia e não precedia essa estrofe, ou seja, o espaço em branco estaria no final das composições do autor anterior, Fernão Garcia Esgaravunha), ou essa primeira estrofe será efectivamente de João Lobeira (podendo as outras duas ter sido acrescentadas em época posterior, eventualmente). Seja como for, e atendendo a toda esta problemática, que nos parece necessitar ainda de melhor atenção, optámos por 
considerar o "Lais de Leonoreta" uma composição de autoria duvidosa, indicando como seus mais prováveis autores João Lobeira ou um Anónimo.

\section{Novos dados de antroponímia e toponímia}

Como referimos no primeiro ponto destas notas, do trabalho de construção desta base de dados saiu reforçada a constatação da ligação estreita que as cantigas trovadorescas mantêm com os contextos sociais e políticos da sua produção. Dois dos elementos que melhor permitem detectar e interpretar essas ligações são a antroponímia e a toponímia presentes nas cantigas. De facto, quer as pessoas, destinatários ou não das cantigas, quer os lugares referidos pelo trovadores nas suas composições definem uma rede de sentido que, na maior parte dos casos, não é fortuita ou meramente pessoal, mas sim social e politicamente orientada. Um dos esforços mais permanentes da equipa foi, pois, o de tentar identificar os lugares e as pessoas referidos mas ainda desconhecidos, tarefa difícil, demorada e frequentemente inconclusiva. Mesmo assim, creio que neste campo a BD apresenta novidades significativas. Irei referir em seguida as entradas de toponímia e de antroponímia nas quais apresentamos dados novos ou fazemos novas sugestões de identificação. Sendo certo que esta questão se liga estreitamente com a interpretação das cantigas e dos seus contextos, matéria que tratarei no ponto seguinte, limitar-me-ei, neste ponto, a enumerar, de forma muito breve e resumida, os lugares e as pessoas em relação aos quais avançamos propostas novas ou alternativas de localização e de identificação. Em algumas delas deter-me-ei um pouco mais demoradamente no ponto seguinte. Em relação à restantes ficará apenas esta chamada de atenção, de forma a possibilitar a discussão dos dados avançados.

No que diz respeito à toponímia presente nas cantigas, e sendo certo que na esmagadora maioria dos casos ela é perfeitamente reconhecível ou reconhecida (cidades e lugares cujos nomes são ainda os mesmos ou cuja localização foi já estabelecida com relativa segurança há mais ou menos tempo), creio que a novidade mais relevante será a proposta que fazemos para o topónimo Losi, que surge numa cantiga de Vasco Rodrigues de Calvelo, e que identificamos como S. João de Luzim, nas margens do Tâmega e perto de Penafiel. Esta localização, que tem origem numa transcrição, feita 
pelo Elucidário de Viterbo, de um documento do século $\mathrm{X}$ onde surge a igreja respectiva (Vol. I, p. $48^{26}$ ), parece, de resto, estar de acordo com a referência a Maior Gil (de Jolda), a dama cantada pelo trovador numa sua outra cantiga, dama cuja linhagem tinha sede em Bravães, nas cercanias de Calvelo (Resende de Oliveira), e não longe de S. João de Luzim. E permite também confirmar os dados biográficos do trovador avançados por este investigador, que localizou duas filhas de um Vasco Rodrigues criadas na mesma área geográfica ${ }^{27}$. Creio, portanto, que Losi poderá ser, efectivamente, S. João de Luzim. Já sobre o sentido destas duas referências muito concretas feitas em cantigas de amor não avançamos qualquer explicação. Mas será este, certamente, um assunto a pedir alguma atenção.

No que toca à localização das numerosas ermidas cantadas pelos trovadores e jograis nas suas cantigas de amigo (no sub-género habitualmente designado por "cantigas de santuário"), muita investigação tem sido feita, em tempos recentes, sobretudo na Galiza (onde se situa a maioria das ermidas), investigação essa cujos resultados procurámos integrar nas respectivas entradas toponímicas. Assim sendo, chamo apenas a atenção para a proposta de localização que avançamos em relação à ermida, até agora mal localizada, de S. Simão de Vale de Prados, cantada na conhecida e notável cantiga de Pero Viviães "Pois nossas madres vam a Sam Simom", e que se baseia no facto de D. Dinis ter dado foral à povoação de Vale de Prados (Macedo de Cavaleiros), povoação por onde passava eventualmente um dos ramos do Caminho de Santiago, e que, aliás, não fica longe de Chacim, sede da linhagem a que pertencia D. Nuno Martins, mordomo-mor do monarca. Trata-se, como é evidente, de uma sugestão ${ }^{28}$, a qual, podendo coadunar-se com a cronologia de Pero Viviães, talvez não se coadune tão bem com a sua eventual nacionalidade galega, sugerida por Resende de Oliveira.

\footnotetext{
${ }^{26}$ Aproveito para referir que o Elucidário de Viterbo está (pelo menos no momento em que escrevo estas linhas) disponível online, através do Google Books, e é pesquisável. As possibilidade novas que este tipo de recursos trazem à investigação merecem, creio, ser sublinhadas.

27 Acrescento que, para esta localização, contei com a preciosa ajuda do meu colega e amigo Prof. José Camões (FLUL), a quem não quero deixar de agradecer publicamente aqui.

28 Já D. Carolina Michaëlis refere que "Val de Prados, com a ermida de San Simão, parece ser uma localidade ao pé de Segóvia, ou em Trás os Montes" (CA, II, p. 886, nota 6). Creio que, mais uma vez, as suas indicações breves indicam caminhos muito produtivos.
} 
Mais brevemente referirei as propostas de localização que fazemos para Ensar (Enxara dos Cavaleiros?) e Pavia (Mora, Alentejo), esta última uma das povoações fundadas por D. Dinis, o que parece de acordo com a temática da cantiga em que é referida e a provável cronologia do seu autor.

Quanto à antroponímia, fizemos um efectivo esforço para apresentar um mínimo de dados sobre todas as figuras que são referidas nas cantigas e que até agora ainda não tinham sido identificadas ou cuja identificação é discutível, e isto pelo menos em relação àquelas que não são apenas referidas por um nome próprio (já que, como é evidente, quando estamos face a uma D. Maria ou a um Rodrigo e não há qualquer outro dado mais concreto na cantiga, impossível se torna localizar a personagem). Em relação a todos os restantes, a BD avança propostas de identificação, quer na forma de dados mais ou menos seguros que conseguimos apurar, quer na forma de sugestões mais ou menos hipotéticas (e por vezes plurais). Sendo que sobre algumas destas personagens me debruçarei um pouco melhor no ponto seguinte, enumerarei em seguida as entradas de antroponímia onde surgem essas novas propostas: Afonso Afonses, Álvaro Rodrigues, Bispo de Cuenca, Camela, D. Álvaro, D. Corral, D. Estêvão, D. Joana, D. Leonor, D. Macia, Deão de Cádiz, Fernão Dias, Fernão Gil, Gonçalo Martins, João Aranha, João de Froião, João Eanes, João Fernandes, Lourenço Bouçom, Martim Fernandes, Martim Xira, Mestre João, Mestre Reinel, Mestre Simion, Pero da Arruda, Pero Fernandes, Pero Garcia Galego, Pero Lourenço, Pero Ordoñez, Pero Peres, Pero Soares, Rui Fafes, Rui Gonçalves, Rui Pais, Sancha Garcia, Sueiro Eanes e Tisso Pérez.

Nem todas as personagens desta lista têm, como é evidente, a mesma importância no corpus trovadoresco que nos chegou. Enquanto algumas delas aparecem em referências mais ou menos pontuais numa ou noutra composição, outras, até pelo número de cantigas em que surgem, são personagens centrais do corpus galego-português (no caso, do corpus satírico). Entre estas últimas, os casos mais salientes (e também os mais problemáticos) serão certamente os de D. Estêvão, Fernão Dias e João Fernandes, personagens à volta das quais se desenvolveram verdadeiros ciclos satíricos de cantigas, há muito delimitados. O que não quer dizer que a sua identificação seja fácil; entre outros motivos porque, como se pode verificar, para nenhum deles é indicado o nome de família. 
O caso de D. Estêvão (ao qual são dirigidas oito cantigas - e isto se se tratar sempre do mesmo D. Estêvão, o que não é seguro) é talvez o mais enigmático. Na verdade, sendo certo que se trata de um nobre, que as cantigas que lhe são dirigidas parecem ter claramente como contexto a guerra civil portuguesa, e que, como todas as restantes que abordam esta temática, o fazem a partir do campo do jovem infante Afonso de Castela (futuro Afonso X), que tomou, como se sabe, o partido de Sancho II, mais estranha se torna a dificuldade que temos em localizá-lo. Durante muito tempo (de D. Carolina a Rodrigues Lapa), este D. Estêvão foi identificado como D. Estêvão Anes, o poderoso chanceler de Afonso III. Mas esta identificação não parece ter fundamento, como defende Resende de Oliveira ${ }^{29}$, opinião que partilho agora integralmente ${ }^{30}$ (pelas razões que se explicam mais detalhadamente da nota geral a uma das cantigas). Assim sendo, e embora não tenhamos conseguido chegar a nenhuma outra identificação alternativa segura, não quisemos deixar de sugerir alguns nomes possíveis, entre os quais talvez os mais plausíveis sejam os de D. Estêvão Martins de Briteiros ou de D. Estêvão Peres de Aboim. Sendo certo que, até pela frequência do nome na época, uma identificação segura deste D. Estêvão será sempre difícil, esperamos que as sugestões avançadas possam reavivar o debate.

Já o caso de Fernão Dias, sempre referido como adiantado ou meirinho do rei (de Castela), é ainda mais problemático, uma vez que, não havendo notícia de nenhuma personagem com este nome nesses cargos, também não é tão claro o contexto político onde se inserem as seis ou sete cantigas que lhe são dirigidas (mas mais uma vez a partir do círculo afonsino). Cremos, como Vicenç Beltran, que esse contexto será o da rebelião nobiliárquica contra Afonso $\mathrm{X}^{31}$, e avançamos, na nota geral a uma das

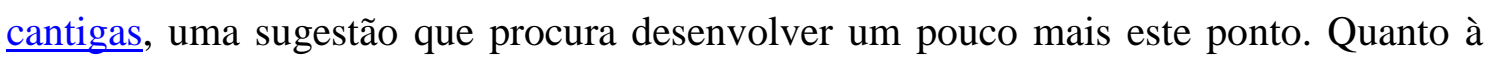
identificação concreta da personagem, procurámos, como no caso anterior, localizar homónimos que se pudessem encaixar nas restantes peças do puzzle, e damos alguma sugestões nesse sentido na respectiva entrada, de entre as quais o galego Fernão Dias,

\footnotetext{
${ }^{29}$ Ver nomeadamente o capítulo, da sua responsabilidade, "Distracções e Cultura", in Leontina Ventura, Afonso III, Círculo de Leitores, Lisboa, 2006.

${ }^{30} \mathrm{Na}$ minha anterior edição das cantigas satíricas, e embora já na época tivesse muitas dúvidas, segui a identificação tradicional, que agora revejo.

${ }^{31}$ Mas não partilhamos a sua tese de que se trataria de D. Estêvão Fernández de Castro, um dos cabecilhas da rebelião, sendo o nome Fernão Dias apenas uma estratégia de disfarce.
} 
referido no Nobiliário do Conde D. Pedro (76G3), e filho D. Diego Gómez de Roa, que foi prior dos Hospitalários em Castela, poderá ser talvez uma boa hipótese. Avançamos, no entanto, outras hipóteses, sempre com carácter hipotético e apenas no sentido de animar igualmente o debate sobre esta tão falada quanto misteriosa figura.

Quanto ao "mouro" João Fernandes, e tomando como certo que se trataria de uma personagem que fisicamente "semelhava mouro" (como diz a rubrica de uma das sete cantigas que lhe são dirigidas), é este um dos casos em que aparentemente estamos perante uma série de meras chacotas pessoais, que não visariam mais do que brincar com o aspecto físico dessa personagem. De D. Carolina a Rodrigues Lapa tem sido esse o entendimento do ciclo, pelo que, ao contrário do que acontece com D. Estêvão ou Fernão Dias, a questão da sua identidade nem sequer tem sido particularmente considerada. Mas, para além do significativo número de cantigas que lhe são dirigidas (o que nos poderá levar a desconfiar, desde logo, que não estaremos perante uma personagem anódina), são pelo menos mais dois os indícios que apontam para um efectivo enquadramento político: o facto de se tratar de um cortesão (uma das cantigas diz-nos que ele é "cortês e casado"), sendo que as chacotas a figuras da corte raramente são inocentes, e o facto de, a partir de uma das cantiga, repleta de referências políticas, podermos datar o ciclo de 1241-1242, por alturas de uma das cruzadas a Jerusalém (para a qual sugerimos também uma outra identificação), sendo que são esses os anos em que, em Portugal, uma parte significativa dos ricos-homens abandona Sancho II, abrindo decisivamente a porta a uma situação que muito em breve levaria à guerra civil e à sua deposição. Seguindo quer a pista da cruzada de Teobaldo I de Navarra, quer a pista portuguesa (note-se, de resto, que, talvez com a excepção de Afonso Anes do Cotom, todos os restantes autores intervenientes neste ciclo são portugueses), avançamos, pois, duas hipóteses alternativas de identificação para este João Fernandes, aguardando também que da sua eventual discussão possa resultar um conhecimento mais seguro desta personagem e do contexto que dá origem ao ciclo.

As outras personagens da lista anteriormente indicada aparecem mais pontualmente, como disse. Com D. Macia entramos na zona das Ordens Militares, zona bastante frequentada pelos trovadores, diga-se, mas que até agora não tinha sido objecto de nenhum estudo específico. A matéria está agora a ser tratada, enquanto tema da sua tese de mestrado, por um dos colaboradores do projecto, o Cláudio Neto, e certamente que 
este trabalho trará algumas novidades, pelo que não assinalo aqui as restantes entradas relativas aos vários membros das Ordens referidos nas cantigas, entradas essas onde também incluímos, desde já, alguns dados provisórios novos.

De citar talvez seja ainda a sugestão que damos na entrada relativa a Pero Lourenço (personagem a quem Pero Gomes Barroso dirige uma cantiga), e que é, muito curiosamente, homólogo do protagonista de uma das Cantigas de Santa Maria (377), um Pero Lourenço referido como pintor (iluminador) ao serviço de Afonso X (que se esquece sistematicamente de lhe dar uma benesse prometida, o que não se afasta muito da temática abordada na composição de Pero Barroso). Podendo ser simples coincidência, creio que poderá, na verdade, tratar-se da mesma personagem.

De resto, com a ajuda de um pequeno mas interessante artigo de Pascual Martínez ${ }^{32}$, creio que localizámos melhor alguns dos mestres e funcionário régios castelhanos referidos nas cantigas (Mestre João, Mestre Simion, D. Tisso Pérez), o mesmo se passando com o Mestre Reinel, referido de passagem numa cantiga de D. Dinis (eventualmente um antepassado dos célebres cartógrafos quinhentistas Jorge e Pedro Reinel). Continua, no entanto, por localizar a personagem a quem o monarca dirige essa mesma cantiga (e mais duas outras), um tal João Bolo, bem como o Meliom Garcia, também satirizado em duas composições suas. Creio que teríamos todo o interesse nestas identificações, já que, mais uma vez, é muito possível que, tanto num caso como no outro, a voz satírica de D. Dinis possa ter um enquadramento político. Nesse sentido, e embora na cantiga que referirei em seguida o rei não indique o nome do satirizado, chamo a atenção para a relação que estabelecemos entre a composição “Melhor ca m’eu governo" e o chamado processo da herança dos Sousa, um das questões mais conhecidas e polémicas do seu reinado. Entramos, no entanto, na matéria do ponto seguinte, para a qual passarei, pois, de imediato.

32 “Aportacion de la documentacion murciana al estúdio de los ofícios de la cancilleria y de la corte de Alfonso X el Sábio. Los ofícios y los oficiales”, in Miscelánea Medieval Murciana, vol. XII. 


\section{Contextos e interpretações}

O facto de as cantigas trovadorescas poderem funcionar como fontes históricas não constitui novidade para ninguém. Muito recentemente, aliás, José Mattoso, embora não se esquecendo de anotar o pouco uso que delas fizeram os historiadores até aos anos 1960, refere-as como uma das três principais fontes primárias do período no que diz respeito à nobreza (as outras duas sendo os Livros de Linhagens e as Inquirições), chamando exactamente a atenção para a sua riqueza e importância ${ }^{33}$. Sublinharei, de qualquer forma, duas características muito próprias deste tipo de textos: trata-se, na verdade, de fontes que têm a particularidade única de nelas ouvirmos directamente a voz dos próprios protagonistas dos factos e conflitos históricos, ou a dos seus colaboradores próximos, e geralmente no exacto momento em que esses acontecimentos ocorrem (no calor da luta, se quisermos); mas trata-se também de textos que se situam no interior de uma prática artística, e, como tal, sujeitos às regras e às normas específicas desse campo. Em conjunto, estas duas características fazem com que, longe de constituírem documentos de sentido unívoco e facilmente interpretável, as cantigas trovadorescas sejam, pois, textos cuja interpretação terá sempre que ter em conta não só as diversas estratégias (pessoais ou de grupo, mas também artísticas) através das quais os seus autores filtram a sua realidade social e histórica imediata, mas também o facto de esses mesmos autores partirem muitas vezes de implícitos perfeitamente descodificáveis pelos seus contemporâneos, e cuja natureza exacta hoje em dia ignoramos ou temos dificuldade em precisar.

Atendendo a este modo múltiplo e filtrado como as cantigas trovadorescas se relacionam com o seu real, compreende-se que a interpretação exacta de muitas delas esteja longe de ser evidente. A investigação que tem vindo a ser desenvolvida em torno destes diferentes aspectos, nomeadamente, como vimos, a que diz respeito aos percursos concretos (geográficos ou sociais) dos autores, ou à toponímia e antroponímia presente nas cantigas, juntamente com as leituras atentas e informadas dos textos que têm vindo

\footnotetext{
33 "The cantigas proved themselves an unmatched source of hints and information on cultural production of the nobility and its mentality", "The Medieval Portuguese Nobility", in Mattoso, José (dir.) The Historiography of Medieval Portugal c. 1950-2019, Instituto de Estudos Medievais, Lisboa, 2011, p. 404.
} 
a ser feitas e discutidas por diversos especialistas, tem permitido, no entanto, avanços significativos no que toca à interpretação de muitos deles. Nas notas gerais que disponibilizamos nas cantigas, ou, por vezes, nas notas de leitura aos versos, procurámos integrar criticamente essas interpretações. Como nos restantes campos, no entanto, também aqui procurámos contribuir para este debate, avançando com leituras e hipóteses de interpretação próprias no que toca a um conjunto de composições ainda relativamente polémicas ou obscuras, e sobre as quais me irei debruçar em seguida. Muito embora sejam estas matérias que exigiriam, em muitos casos, desenvolvimentos mais demorados, fá-lo-ei aqui necessariamente de forma breve e não exaustiva, esperando a elas poder regressar num futuro mais ou menos próximo.

Antes, porém, e de forma a poder enquadrar, desde já, os casos em análise, gostaria de lembrar que, numa perspectiva geral, os contextos históricos que mais abertamente deixam marcas nas cantigas trovadorescas são exactamente os que dizem respeito aos conflitos políticos mais marcantes do século XIII e primeiras décadas do século XIV ibéricos, nomeadamente, e por ordem latamente cronológica, a guerra civil portuguesa, com a deposição de D. Sancho II e a subida ao trono de seu irmão Afonso III, a rebelião nobiliárquica contra Afonso X, o conflito sucessório deste monarca com seu filho, o futuro Sancho IV, e, posteriormente, o conflito sucessório entre D. Dinis e seu filho, o infante Afonso (futuro Afonso IV), sem esquecer, obviamente, ao longo dos mais de 150 anos em que se desenvolve a arte dos trovadores e jograis, os conflitos entre os vários reinos ibéricos (nomeadamente de Castela com Navarra ou com Aragão), e, sobretudo, a chamada Reconquista cristã, com os seus avanços, recuos, traições, alianças, partidas e regressos, cenário sempre presente, nem que seja como pano de fundo dos cantares. O que não quer dizer que sejam estes os únicos contextos políticos detectáveis no nosso corpus. Até porque, bem antes de 1243, data do regresso do Conde de Bolonha a Portugal, já as vozes dos trovadores e jograis se faziam ouvir, sendo mesmo que uma das mais antigas cantigas que nos chegaram, a já citada "Ora faz host'o senhor de Navarra", do português João Soares de Paiva e datável de finais do século XII, versa exactamente, como é sabido, uma situação política específica (no caso, os conflitos entre Navarra e Aragão). 
Seguindo também uma ordem mais ou menos cronológica, iniciarei, pois, este breve passagem por algumas das novas propostas de interpretação que avançamos na $\mathrm{BD}^{34}$, regressando à composição de D. Garcia Mendes de Eixo já anteriormente referida, “Alá u nasq la Torona", composição provavelmente datada dos anos imediatamente anteriores a 1217, ano do regresso a Portugal do trovador, depois de alguns anos de exílio. Neste caso, e dadas até as já referidas dificuldades de edição do texto e que tornam o resultado final bastante inseguro, podem ler-se essas propostas nas diversas notas de leitura aos versos, nomeadamente as do primeiro e do último. São hipóteses de interpretação que valorizam a referência à Toronha, região do sul da Galiza onde D. Garcia casou (como justamente referem todos os que se têm debruçado sobre a cantiga), mas igualmente região longamente reivindicada pela coroa portuguesa. Assim sendo, creio ser bem possível que a composição, que comporta muito certamente uma dimensão política, tenha algo a ver com este último contexto. A nossa sugestão interpretativa, avançada como uma mera hipótese de trabalho, vai nesse sentido, mas necessitará, seguramente, de uma atenção mais demorada.

Indirectamente relacionada com D. Garcia Mendes de Eixo é a conhecida composição de D. Gil Sanches “Tu que ora vens de Montemaior”, que já D. Carolina Michaëlis claramente relacionava com o conflito entre Afonso II e suas irmãs, dado o papel que neste conflito desempenhou a vila de Montemor-o-Velho, praça forte da infanta D. Teresa. Chamamos a atenção, neste caso, para a nova proposta de datação de Resende de Oliveira para a cantiga, com a qual concordamos inteiramente, e que aponta para o ano de $1223^{35}$, data do tratado de paz entre o novo monarca, Sancho II, e suas tias, confirmado em Montemor exactamente por D. Garcia Mendes de Eixo (pai de D. Maria Garcia de Sousa, a provável senhora cantada na composição, e com quem D. Gil Sanches se ligou). Mais do que sugerir qualquer eventual ligação entre esta cantiga a anteriormente referida, gostaria de sublinhar, neste momento, dois aspectos: por um lado, o peso que parecem ter as relações pessoais ou de parentesco no desenvolvimento

\footnotetext{
${ }^{34}$ Como disse, irei debruçar-me apenas sobre as composições polémicas ou obscuras, em relação às quais propomos novas interpretações. Esta viagem cronológica pelo corpus trovadoresco não representa, pois, um resumo de todos os contextos políticos e sociais aludidos nas cantigas, já que muitas delas não oferecem dificuldades de interpretação ou foram há mais ou menos tempo interpretadas em formas pacíficas para a generalidade dos especialistas.

${ }^{35}$ D. Carolina apontava para o ano de 1213, data do cerco de Montemor pelas tropas de Afonso II.
} 
da arte trovadoresca, aspecto que tem vindo a ser gradualmente valorizado em investigações recentes (Resende de Oliveira, Souto Cabo); e por outro lado, chamar a atenção para quão lacunar é o nosso conhecimento da arte trovadoresca galegoportuguesa nestes seus inícios (já que não creio credível a hipótese de qualquer dos trovadores ter apenas composto uma única cantiga), factor que não só condiciona necessariamente a interpretação de algumas cantigas mais antigas, mas que, de forma mais geral, aconselhará uma certa prudência no que toca às explicações gerais sobre as suas origens.

A aceitarmos a nova cronologia para D. Lopo Lias, já anteriormente referida, de anos não muito posteriores propomos datar o extenso ciclo de cantigas que este trovador galego dirige aos infanções de Lemos. Afastando-se das interpretações tradicionais, que situavam estas cantigas numa zona meramente lúdica, Vicenç Beltran, num trabalho relativamente recente ${ }^{36}$, coloca em cima da mesa a hipótese de estarmos perante um ciclo satírico com conotações políticas. Embora não o sigamos na interpretação concreta que avança para esse contexto, cremos que Beltran aponta na direcção certa, e sugerimos uma interpretação alternativa. Assim, tal como indicamos na nota geral da primeira cantiga do ciclo, foi em Benavente, localidade leonesa próxima de Zamora (referida explicitamente na segunda cantiga), que, a 11 de Dezembro de 1230, foi assinado o importante tratado pelo qual as infantas Sancha e Dulce, filhas de Afonso IX de Leão, renunciavam ao seus direitos sobre a coroa deste reino a favor do seu meioirmão Fernando III, na época já rei de Castela, desta forma se concretizando, pela primeira vez, a unificação dos dois reinos. Do nosso ponto de vista, é muito possível, pois, que o galego Lopo Lias componha este conjunto alargado de cantigas neste contexto (e se coloque politicamente do lado das infantas), mas, mais uma vez, é esta uma sugestão que necessitará de uma análise mais demorada.

Dos anos seguintes, ainda segundo uma nova hipótese que avançamos, poderá datar a cantiga que Pero da Ponte dirige a um D. Álvaro, rico-homem acusado de tratar mal os seus escravos mouros, isto se aceitarmos que se trata de D. Álvaro Pérez de Castro, herói da conquista de Baeza e um dos braços direitos de Fernando III, mas que teve um

\footnotetext{
36 "Lopo Liáns, em cas da Ifante", in Medievalismo en Extremadura - Estudios sobre Literatura y Cultura Hispánicas de la Edad Media, Cáceres, Universidad de Extremadura, 2009.
} 
breve e agudo conflito com o monarca entre os anos de 1234 e 1236, exactamente após a conquista desta praça. Poeta áulico por excelência, vemos Pero da Ponte acompanhar de perto os monarcas castelhanos (depois de Fernando III, Afonso X), sempre defendendo as suas posições ao longo dos mais de 40 anos em que a sua carreira está documentada. Pensamos, pois, que o mesmo se passará nesta composição, e que, ao dirigir-se ao satirizado apenas pelo seu nome próprio, D. Álvaro, Pero da Ponte partirá do princípio de que não haverá confusão possível, ou seja, que se trata de uma figura suficientemente conhecida para dispensar qualquer outro dado identificativo. A nossa pesquisa e consequente sugestão de identificação partiu deste princípio. E embora avancemos também, na respectiva nota antroponímica, com uma outra identificação alternativa para este D. Álvaro (que remeteria a composição para o contexto dos conflitos sucessórios de Afonso X com o infante Sancho, em época bem posterior), cremos que esta cantiga, inserindo-se claramente no cenário da chamada Reconquista (como indica a referência aos mouros), parece mais imediatamente situar-se no período acima indicado, e datar, pois, dos primeiros anos da actividade do segrel.

Como antes referi, a situação política em Portugal ao longo da década de 1240, ou seja, a guerra civil e os anos imediatamente posteriores à subida ao trono de Afonso III, encontra-se largamente documentada nas cantigas trovadorescas (mas sobretudo a partir do ponto de vista contrário ao novo monarca ${ }^{37}$ ). Para além das três bem conhecidas cantigas sobre "a traição dos alcaides" e do ciclo em torno de D. Estêvão, já antes referido, é também neste contexto que teremos de inserir os diversos ataques contra a linhagem dos Briteiros, cujo deão, D. Rui Gomes, foi, como é sabido, não só um dos principais braços direitos do Conde de Bolonha, mas o seu primeiro mordomo-mor após a sua subida ao trono. A linhagem foi, de resto, objecto de um minucioso e rigoroso estudo de Leontina Ventura e Resende de Oliveira ${ }^{38}$, artigo que me dispensa de maiores explicações. No caso, gostaria apenas de chamar a atenção para os novos dados que incluímos nas notas antroponímicas da célebre "Gesta de maldizer" que D. Afonso

\footnotetext{
${ }^{37}$ Porque visivelmente compostas no círculo do infante Afonso (futuro Afonso X), que apoiou Sancho II.

38 "Os Briteiros (séculos XII-XIV) 4. Produção Trovadoresca", in Os Reinos Ibéricos na Idade Média. Livro de Homenagem ao Professor Doutor Humberto Carlos Baquero Moreno, coord. Luís Adão da Fonseca et al., vol. II, Livraria Civilização, Porto, 2003, pp. 763-777
} 
Lopes de Baião dirige a Rui Gomes ${ }^{39}$, e que procuram identificar melhor os numerosos cavaleiros, vassalos dos Briteiros, nela referidos. De entre todos, salientarei aqui, pelos motivos a seguir explicados, Lopo Gato, o último dos cavaleiros a ser referido (v. 57). Trata-se, na verdade, de um dos irmãos de D. Guiomar Afonso Gata, a dama maliciosamente referida por Rui Queimado em duas cantigas que classificamos como de género incerto ("Preguntou João Garcia" e "Pois que eu ora morto for"). D. Guiomar foi muito provavelmente, como avança num trabalho mais recente Leontina Ventura ${ }^{40}$, barregã de Afonso III (antes de 1254, data provável do seu casamento com o seu primo Pero Pais Curvo de Alvarenga). Juntando todos estes dados, será, pois, plausível pensar que os Gato, pelas suas ligações aos Briteiros e ao novo quadro político resultante da ascensão ao trono do Conde de Bolonha, são também, enquanto linhagem, um alvo satírico, e que as cantigas que Rui Queimado dirige a D. Guiomar se poderão indirectamente inserir neste contexto. De resto, a outra conhecida cantiga de D. Afonso Lopes de Baião, "Em Arouca ũa casa faria", talvez datável do período em redor de 1250, e na qual o trovador satiriza o ambiente, a seu ver devasso, que se viveria neste conhecido mosteiro feminino, poderá igualmente ter ainda algo a ver com as tensões políticas que persistiam nos primeiros anos do reinado do Bolonhês. Na nota geral a essa cantiga, disponibilizamos os dados, já sugeridos por Resende de Oliveira, respeitantes à identificação da jovem freira que D. Afonso de Baião aí parece cobiçar. Refiro aqui o facto porque, entre as candidatas possíveis estarão Dórdia Gil de Soverosa e Guiomar Gil de Riba de Vizela, exactamente as donzelas cuja entrada no convento é lamentada por João Garcia de Guilhade numa composição. Assim sendo, e pertencendo estas donzelas a linhagens que se mantiveram fiéis a D. Sancho II, sugerimos também, na nota geral a esta cantiga de Guilhade, que o seu sentido poderá comportar igualmente

\footnotetext{
${ }^{39}$ Embora a rubrica da cantiga refira que ela foi feita a "D. Mendo e seus vassalos", concordamos, em princípio, com a sugestão de Leontina Ventura e Resende de Oliveira de que se tratará de um erro dessa mesma rubrica e que D. Belpelho, a "velha raposa", seja seu pai. De qualquer forma, acrescento que não resulta muito claro em que circunstâncias D. Afonso Lopes de Baião, que encontramos, $\operatorname{logo}$ em 1250, ao lado de Afonso III, teria composto esta contundente sátira contra o seu mordomo-mor. Resende de Oliveira (no capítulo "Distracções e Cultura" da biografia de Afonso III, ob. cit., p. 243) parece pressupor que teria sido no cenário da conquista de Sevilha (1248), em que participou, o que significaria que, nessa altura, o senhor de Baião estaria ainda no campo dos que se opunham a Afonso III. A referência a Lopo Gato feita na composição, e que analisarei em seguida, poderá vir de encontro a esta suposição. Mas não quero deixar de referir aqui que poderíamos igualmente colocar a hipótese de, dando razão à rubrica, se tratar de uma cantiga bem mais tardia, eventualmente datando da época em que, como sugere José Augusto Pizarro (ob. cit., I, p. 294, nota 7), D. Afonso Lopes de Baião terá eventualmente abandonado a corte de D. Dinis, seguindo a rainha-mãe D. Beatriz para Castela.

${ }^{40}$ D. Afonso III, Lisboa, Círculo de Leitores, 2006, p. 212.
} 
uma dimensão política, ou seja, constituir um irónico remoque às linhagens derrotadas (mais do que um sincero lamento pela triste situação das donzelas, uma vez que os dados biográficos do trovador parecem indiciar a sua proximidade aos Sousa, partidários do novo monarca).

Fazendo um breve ponto do que anteriormente foi dito, o que pretendo salientar é que, para além das cantigas há muito apontadas como tendo relações evidentes com o conturbado período da deposição de D. Sancho II e subida ao trono de seu irmão, algumas outras se poderão igualmente inserir nesse contexto, particularmente as que o fazem pela via indirecta das alusões a diversas mulheres das linhagens em conflito (e aqui chamarei a atenção para o facto de não se tratar, em geral, de cantigas declaradamente satíricas, mas antes de um género a que, por isto mesmo, chamámos “incerto").

Mas não serão, de resto, apenas estas: pensamos, na verdade, que a composição que Rodrigo Anes Redondo (mas discutiremos a autoria da cantiga em seguida) dirige ao "novo rico" Sueiro Fernandes, tão ironicamente pintado com os seus sapatos dourados em todas as estações, poderá igualmente situar-se no mesmo período. Este Sueiro Fernandes poderá ser, de facto, o "bom cavaleiro" que o Livro de Linhagens do Conde D. Pedro (LL68A3) diz ter sido um dos companheiros do Conde de Bolonha na lide de Santarém, um dos episódios mais marcantes da fase inicial da guerra civil. Proveniente de uma linhagem de cavaleiros-vilãos, alvo muito apetecido pelos trovadores, é plausível que este Sueiro Fernandes possa ser, pois, o alvo da cantiga (assim indirectamente dirigida, como se compreende, ao "bando" do Conde). O facto de os Redondo terem sido também uma das linhagens que se manteve fiel a Sancho II parece corroborar esta nossa interpretação. E, neste caso, datando a composição destes anos, resolveríamos também o problema da sua autoria, problema resultante de $\mathrm{V}$ a atribuir a Rodrigo Anes Redondo e B e C a seu filho, Fernão Rodrigues - optando decididamente pelo pai. A este propósito, voltarei, por momentos, cronologicamente um pouco atrás, para referir que este mesmo Sueiro Fernandes é um meio-irmão de Martim Xira, personagem referida na polémica cantiga "Pois não hei de D. Elvira", cantiga de autoria muito controversa (e já antes referida a propósito da inicial antropomórfica de A), mas que certamente aludirá ao alegado rapto de D. Elvira de Sousa por Rui Gomes de Briteiros, episódio ocorrido por volta de 1230. Não me deterei aqui nesses complicados 
problemas de atribuição da cantiga (brevemente resumidos na nota respectiva da BD), mas, sendo mais ou menos pacífico que a voz que nela ouvimos é a de Rui Gomes, a referência a Martim Xira (que o aconselha, v. 7), indica-nos que ele seria um dos cavaleiros do seu bando. Se as coisas estão todas ligadas, como parecem estar, não admiraria assim que encontrássemos o seu irmão Sueiro Fernandes ao lado do Conde de Bolonha na lide de Santarém, e que a ele se dirigisse um fiel partidário do partido oposto, como foi Rodrigo Anes Redondo.

Esta nebulosa de ligações familiares e fidelidades políticas não se fica, no entanto, por aqui, já que Rui Garcia de Paiva, o alvo da cantiga de Afonso Mendes de Besteiros já antes igualmente referida no ponto 3 ("O $\mathrm{O}$ arrais de Roi Garcia”), foi casado, em primeiras núpcias, exactamente com uma filha de Martim Xira, Teresa Martins Xira ${ }^{41}$. Atendendo ao facto de Afonso Mendes de Besteiros ser, como também se disse, o autor de uma das conhecidas cantigas sobre a "traição do alcaides", não é, pois, impossível que este ataque que dirige a Rui Garcia de Paiva obedeça à mesma estratégia política e se situe ainda no rescaldo imediato da guerra civil, ou seja, num momento bem anterior ao que tradicionalmente tem vindo a ser indicado para a composição (e que tem apontado para um momento posterior a 1263, ano a partir do qual Rui Garcia adquire grande visibilidade na corte de Afonso III). De resto, as referência feitas na cantiga a Leiria e a Santarém, cidades que desempenharam um papel central no período agudo do conflito militar (e que foram bases do Conde de Bolonha), parece corroborar esta interpretação. A ser este o caso, como penso, teríamos também que recuar a cronologia do D. Martinho cuja morte é igualmente referida na cantiga, descartando as pistas que têm sido seguidas para a sua identificação e procurando outras (tratar-se-á de Martim Anes de Riba de Vizela? de Martim Anes, irmão do chanceler Estêvão Anes?).

Ainda tendo como contexto este conturbado período, não queria deixar de fazer uma muito breve referência às três ou quatro cantigas que o abordam a partir da posição tomada pelas Ordens Militares no conflito, nomeadamente os Hospitalários, entre as quais duas tenções que têm nitidamente como cenário a corte castelhana ( $\underline{\text { uma }}$ entre Vasco Gil e o próprio Afonso X, outra entre o mesmo Vasco Gil e Pero Martins). Neste

\footnotetext{
${ }^{41}$ Os dados são de Resende de Oliveira, que segue Leontina Ventura. Os Livros de Linhagens referem que D. Teresa Martins casou com Lopo Rodrigues de Paiva (primo de Rui Garcia).
} 
caso, no entanto, limitar-me-ei a remeter para os dados que disponibilizamos nas notas gerais destas composições, e que, como disse, poderão em breve vir a ser completados com os resultados da investigação que um dos elementos da equipa está a desenvolver sobre esta matéria.

Esta curta referência servir-me-á, de qualquer forma, para fazer a passagem para a corte castelhana, cenário eventual de muitas das cantigas que acabei de referir, mas igualmente, como seria de esperar, cenário de muitas outras cujos motivos se prendem com os conflitos políticos aí especificamente vividos. Já antes referi ser este o caso de um dos momentos mais conturbados do reinado do Rei Sábio, a revolta dos seus principais ricos-homens, ocorrida entre ao anos de 1271-1274 (como referidos foram também, nesta matéria, os dados novos que avançamos relativos à identidade do "adiantado" Fernão Dias). As pesquisas relativas ao bispo de Cuenca, contra quem Pedro Amigo de Sevilha dirige uma cantiga, "Um bispo, diz aqui, por si", parecem indicar igualmente que esta composição poderá datar desses mesmos anos. De qualquer forma, realço que também o comportamento das Ordens Militares no conflito parece ser chamado à liça em várias cantigas. Neste sentido, vai a nova interpretação que avançamos para a conhecida cantiga do português Pero Mendes da Fonseca, "hegou Paio de más artes", que situamos exactamente neste período. Tomando como plausível que este Paio não será outro senão o célebre mestre da Ordem do Hospital D. Paio Peres Correia (como já antes tinham proposto duas investigadoras ${ }^{42}$ ), figura largos anos muito próxima de Afonso X, procurámos entender em que circunstâncias poderia ele ser atacado do interior do círculo afonsino, e concluímos que só o poderia ter sido a partir de 1272, altura em que as relações entre o monarca e poderoso Mestre se degradaram substancialmente (pelo alegado apoio deste último aos revoltosos). Remeto, no entanto, para a nota geral da composição, onde esta proposta é um pouco melhor fundamentada. De resto, também não é impossível que a cantiga de Gil Peres Conde, “Nom é Amor em cas d'el-rei', composição em tom de sirventês moral, mas onde, na estrofe final, se faz uma distinção clara entre os fiéis Templários e os péssimos Hospitalários, deva situar-se exactamente no mesmo contexto político (já que a Ordem do Templo parece ter sido a única que se manteve fiel ao monarca nesse período).

\footnotetext{
${ }^{42}$ Ver a Nota Geral da cantiga para as referências bibliográficas.
} 
Chego assim a outra das mais complicadas cantigas do todo o corpus trovadoresco, a composição de Caldeirom, "Os d'Aragom, que soem donear", cantiga claramente política, e onde as referências depreciativas aos Hospitalários são também evidentes. Antes de me debruçar sobre a nova proposta de interpretação que avançamos, será conveniente lembrar que esta cantiga, mais até do que a cantiga de D. Garcia Mendes d'Eixo antes referida, congrega em si todas as dificuldades possíveis de encontrar no nosso corpus: um texto altamente deturpado nos manuscritos e, por isso mesmo, dificílimo de editar, a ausência de qualquer rubrica explicativa, e, no que toca ao seu autor, a ausência de dados e a incerteza quanto à sua cronologia. Compreende-se assim que interpretar tão problemática cantiga seja uma tarefa arriscada. Sendo certo que a composição se situa claramente num contexto de conflito entre os reinos ibéricos (entre Aragão e provavelmente Castela), mas sendo igualmente certo ser essa uma situação por demais frequente ao longo do século XIII e inícios do XIV, a cronologia do seu autor será aqui um factor decisivo. À nossa nova proposta de interpretação não são, pois, alheias as novas hipóteses de Ron Fernández sobre a biografia de Caldeirom, brevemente resumidas na sua nota biográfica, e que avançam a possibilidade de estarmos perante um autor activo, não dos finais do século XIII, e na corte de Sancho IV, como se supunha, mas em décadas anteriores. Assim sendo, e juntando os dados do puzzle que poderemos, com mais ou menos segurança, retirar da cantiga (a sátira aos Aragoneses e Catalães, feita com a referência muito explícita, e até surpreendente, a donas, o ataque aos Hospitalários, e a referência a Fariza, ou Ariza, vila historicamente de fronteira entre os reinos de Aragão e Castela), propomos que a cantiga poderá eventualmente relacionar-se com um dos episódios político-familiares mais marcantes do confronto entre Afonso X e o seu herdeiro, o infante Sancho, e que foi a fuga, no início de 1278, da esposa do monarca, a rainha D. Violante, para junto de seu irmão, D. Pedro III de Aragão (que a foi receber em Ariza), levando consigo os infantes De la Cerda e a mãe destes últimos, D. Branca, viúva do malogrado primogénito do Rei Sábio, D. Fernando. Mais uma vez remeto para a Nota Geral da cantiga onde a nossa proposta de interpretação é um pouco mais desenvolvida e melhor justificada.

Ainda destes anos propomos datar igualmente mais duas composições: uma delas é o pranto satírico de Pero da Ponte, "Mort’é Dom Martim Marcos, ai Deus! Se é verdade". $\mathrm{O}$ ataque indirecto (mas explicitado pela rubrica da cantiga) que nele é feito ao infante 
D. Manuel, irmão mais novo de Afonso X, só pode situar-se, de facto, entre o momento em que o infante se afasta politicamente do irmão (do qual, até aí, fora muito próximo) para passar a apoiar o seu sobrinho, o infante Sancho, e a data da sua morte, ou seja entre os anos 1277 e 1283. Esta interpretação implica também que estaremos face a uma das últimas cantigas de Pero da Ponte, cuja vida teremos de prolongar um pouco mais (já que Resende de Oliveira, seguindo Vicenç Beltran, sugere como data da morte do segrel o ano de 1275).

E também do mesmo período, segundo uma nova hipótese que avançamos, datará a conhecida cantiga que Afonso $\mathrm{X}$ dirige a um dos seus companheiros dilectos, $\mathrm{O}$ português Gonçalo Anes do Vinhal. Trata-se da longa composição “Dom Gonçalo, pois queredes ir daqui pera Sevilha”, que apresenta também alguns problemas de edição (já antes referidos), e que tem sido objecto de alguma discussão entre especialistas de várias áreas (o Prof. José Mattoso, por exemplo, entrou igualmente no debate ${ }^{43}$ ). No caso, e contrariamente à interpretação mais comum que aponta como cenário provável da cantiga os conflitos entre Afonso X e o seu irmão D. Henrique, ocorridos na década inicial do seu reinado (1253-1258), pensamos que, não havendo notícia de qualquer contencioso entre o Rei Sábio e D. Gonçalo nesses anos (muito pelo contrário, é exactamente em 1257 que o monarca lhe concede o importante senhorio de Aguilar), será para os anos finais do reinado que deveremos apontar, anos em que, efectivamente, D. Gonçalo, se afasta finalmente do monarca para tomar o partido do infante Sancho. De resto, o tom cordato mas igualmente sentido da cantiga, na qual o rei faz questão em recordar a D. Gonçalo o seu percurso de ascensão (pessoal e material) em Castela, parece confirmar esta interpretação. Procurámos ainda integrar uma eventual explicação para as referências feitas na composição a João Soares Coelho, mas creio que será este igualmente um assunto a necessitar de mais demora.

Finalmente, e permanecendo ainda no cenário da corte castelhana de Afonso X, gostaria de fazer uma referência breve a um dos ciclos mais discutidos do corpus galegoportuguês, o ciclo habitualmente designado como "a questão da ama". Trata-se de um conjunto de, pelo menos, sete composições, seis das quais compostas na sequência de

\footnotetext{
43 "João Soares Coelho e a gesta de Egas Moniz", in Portugal Medieval - Novas Interpretações, IN/CM, $2^{a}$ edição, Lisboa, 1992, pp. 409-434.
} 
uma primeira de João Soares Coelho, "Atal vej’eu aqui ama chamada", cantiga, em princípio, de amor, na qual o trovador faz o elogio de uma "ama" (e não de uma senhor, como seria de regra). Vários trovadores comentam jocosamente a questão, e o próprio João Soares Coelho faz duas intervenções suplementares em sua defesa. Remetendo para a nota geral dessa primeira cantiga, onde se faz um breve resumo das diversas interpretações que têm sido avançadas para este ciclo, gostaria apenas de salientar que a mais recente delas, proposta por Vicenç Beltran, entende o ciclo como uma espécie de debate festivo celebrando o nascimento de um infante real (a "ama" sendo exactamente a ama de leite desse infante), e situa-o em torno do nascimento de D. Dinis $(1261)^{44}$. Como avançamos nessa nota geral, a cronologia de alguns intervenientes no "debate" talvez não se coadune com esta aliciante hipótese. Mas a interpretação genérica do ciclo parece-me muito plausível, pelo que creio que será este novamente um assunto a merecer uma investigação mais demorada (seguindo eventualmente a pista de uma infanta e não de um infante, já que as cantigas parecem aludir a uma criança do sexo feminino).

Avanço agora para os inícios do século XIV, para referir também brevemente uma cantiga de amor de Pero Viviães, “A Lobatom quer'eu ir", a qual, afastando-se igualmente da norma do género, não só contém elementos muito concretos de toponímia, como é já visível neste incipit, como os completa em seguida com a referência a uma D. Joana e a uma sua irmana. Uma vez que Lobatom será, muito possivelmente, Torre Lobatón, e que essa praça castelhana a norte do Douro foi ocupada, em 1305, por João Nunes de Lara II, no contexto do conflito que opunha os infantes De la Cerda (cujo partido o Lara tomou) ao jovem monarca Fernando IV, é muito possível que as senhoras referidas sejam exactamente as irmãs de D. João de Lara, D. Joana e D. Teresa Nunes de Lara. Ambas foram, de resto, pelos casamentos que efectuaram, peões importantes no xadrez político da época (como se poderá ver nas respectivas notas antroponímicas). Assim sendo, e uma vez que a cronologia de Pero Viviães torna esta hipótese plausível, creio que estaremos, de facto, face a uma cantiga de amor que, muito provavelmente, teria sobretudo um muito concreto sentido de

\footnotetext{
44 "Tipos e temas trovadorescos, XV. Johan Soarez Coelho y el ama de don Denis", Bulletin of Hispanic Studies, 75, 1998, pp. 13-43.
} 
louvor à linhagem dos Lara. Esta hipótese poderá, de resto, orientar eventualmente as pesquisas futuras sobre Pero Viviães, trovador sobre o qual quase nada sabemos.

Regresso, finalmente, à corte portuguesa, que foi, como é sabido, o cenário preferencial da última geração de trovadores e jograis. Já antes me referi a uma cantiga de D. Dinis que muito provavelmente alude à complicada questão da herança dos Sousa. Mas são os anos finais do reinado deste monarca que mais profusamente parecem estar documentados no nosso corpus, muito particularmente no que diz respeito ao conflito que o opôs ao seu herdeiro, o infante Afonso, e aos seus partidários (sempre, sem excepção, atacados nas cantigas). A questão não termina, de resto, com a morte de D. Dinis, mas prolonga-se claramente pelas primeiras décadas do reinado de Afonso IV, onde encontramos a última geração de trovadores num alinhamento político semelhante. Assim, são por demais conhecidas, neste período mais tardio, as cantigas que os trovadores e jograis do círculo de D. Pedro, conde de Barcelos, dirigem, de forma directa ou indirecta ${ }^{45}$, contra D. Miguel Vivas, um dos braços-fortes do monarca. Pensamos, no entanto, que várias outras composições se podem relacionar estreitamente com o conflito, algumas delas datando ainda no reinado de D. Dinis. São cantigas onde se fazem ataques a personagens diversas, aparentemente com mera intenção de zombaria pessoal. Analisadas, no entanto, essas personagens no xadrez político e no contexto das linhagens a que pertencem, a intenção política parece evidente.

Nesta última geração de trovadores três linhagens muito próximas de D. Afonso (infante e rei) parecem assim ser alvos preferenciais: os Pimentéis, os Ataíde e os Pereira. A estas acrescentarei os Cunha, que também o poderão ter sido, como veremos.

A Fernão Vasques Pimentel dirige João de Gaia uma cantiga muito conhecida, " asno no mercado", onde satiriza os ziguezages do seu percurso político (em seis meses, três senhores, sendo que o último é o infante rebelde). Mas não será, no entanto, a única. $\mathrm{Na}$ verdade, ainda ao mesmo Fernão Vasques Pimentel, embora de forma mais subtil e indirecta, se dirigirá, segundo cremos, a cantiga de D. Afonso Sanches, "Conhocedes a

\footnotetext{
${ }^{45}$ Neste último caso está a cantiga contra um tal Rui Fafes, que tenta esconder a calva com uma grande e luxuosa capa, mas que, na verdade, é o marido de uma sobrinha de D. Miguel Vivas (sendo que a rubrica da cantiga refere explicitamente o bispo, damos, na nota antroponímia relativa a Rui Fafes, mais alguma informação sobre o percurso deste cavaleiro).
} 
donzela", cantiga onde o filho predilecto de D. Dinis (e que esteve no centro do conflito) se detém maliciosamente nos diversos nomes pelos quais uma senhora iria sendo sucessivamente conhecida. Uma vez que a cantiga pode ser facilmente consultada, chamo a atenção apenas para a nota toponímica que inserimos no v. 26, a propósito da alusão a Zamora, alusão que certamente será tudo menos inocente, princípio que orientou a nossa pesquisa. Na verdade, natural de Zamora era a mulher de Fernão Vasques, D. Maria Rodrigues, como refere explicitamente D. Pedro no seu Nobiliário (35G2), pelo que parece bem possível que, mais uma vez, a cantiga seja bem mais do que um mero divertimento inconsequente, e que as mulheres sirvam aqui novamente de verdadeiras armas de arremesso no combate político. Também indirectamente endereçada ao mesmo Fernão Vasques, mas agora através de uma sua sobrinha, poderá ainda ser a divertida cantiga do Conde D. Pedro "Natura das animalhas", composição onde o Conde de Barcelos brinca com a relação "contranatura" de uma Camela com um Bodalho (porco pequeno). Como avançamos na respectiva nota antroponímica, esta Camela, que a rubrica da cantiga diz chamar-se Mor Martins, poderá ser, na verdade, Mor Nunes Camela, em relação à qual o Conde diz no seu Nobiliário que "foi monja de Arouca e mui grande puta" (35F3). Filha de Nuno Gonçalves Camelo, um dos próximos de Afonso IV (infante e rei), era, como disse, sobrinha de Fernão Vasques Pimentel ${ }^{46}$. De resto, também não seria impossível que a mordaz cantiga que o mesmo Conde D. Pedro dirige a um Mestre não identificado de uma Ordem Militar também não identificada ("Um cavaleiro havia") tivesse como destinatário o membro mais ilustre desta família, o Prior do Hospital D. Estêvão Vasques Pimentel. Mas retomaremos esta cantiga um pouco mais adiante.

Quanto aos Ataíde, eles comparecem na pessoa de Martim Gil, o Feio (o nome que os próprios Nobiliários dão a Martim Gil de Ataíde), a quem Estêvão da Guarda dirige uma cantiga ("Martim Gil, um homem vil"). O facto de a rubrica dessa cantiga indicar

\footnotetext{
${ }^{46}$ Note-se, de resto, que, como indica José Mattoso, a linhagem dos Pimentéis é uma das que é sofre alterações na refundição de 1360-65 do Nobiliário do Conde D. Pedro, que passa a incluir, logo na abertura do capítulo (XXXV) uma assaz extensa narrativa destinada a reabilitar a memória de Vasco Fernandes Pimental, pai de Fernão Vasques (já que na versão do Conde, que o refundidor também resume, D. Vasco teria sido concebido ainda no tempo em que sua mãe, D. Sancha Martins, era casada com o seu primeiro marido - sendo D. Vasco filho do segundo) (Mattoso, José, Introdução a Livro de Linhagens do Conde D. Pedro, Academia das Ciências, Lisboa, 1982, pp. 49-50). Como veremos em seguida, e no que toca às figuras que surgem nas cantigas desta última geração de trovadores, estas refundições posteriores do Nobiliário do Conde não parecem limitar-se aos Pimentéis.
} 
que era escudeiro, pode levar-nos a pensar que a sátira datará ainda do reinado de D. Dinis, como talvez todas as anteriores.

Mais surpreendente poderá parecer a menção que fazemos aos Pereira, uma vez que nenhum membro desta linhagem, então em plena ascensão, comparece explicitamente nas cantigas. Avançamos, no entanto, a hipótese de a figura de D. Álvaro Gonçalves Pereira, mestre dos Hospitalários e Prior do Crato, estar no centro de um dos mais consistentes ciclos de cantigas desta última geração de trovadores, o que é dirigido a um tal Álvaro Rodrigues, e que se compõe, pelo menos, de seis cantigas, cinco de Estêvão da Guarda e uma do Conde D. Pedro. Mais uma vez partimos do princípio que uma personagem anódina não mereceria dos trovadores tamanha atenção. Assim, e como avançamos na respectiva nota antroponímica, este Álvaro Rodrigues poderá ser talvez identificado como Álvaro Rodrigues Redondo, neto ou mesmo filho bastardo do trovador Rodrigo Anes Redondo, e que o Nobiliário do Conde D. Pedro diz ter sido criado de D. Álvaro Gonçalves Pereira ${ }^{47}$. Na referida nota apresentamos as razões em que nos fundamentámos e justificamos um pouco melhor esta nossa hipótese. De qualquer forma, e a ser assim, é possível que as referidas cantigas, que insistem numa viagem da personagem ao "ultramar", datem do período inicial da carreira de D. Álvaro, anterior à chefia da ordem (1336). A não ser que tenhamos que incluir neste ciclo a já referida cantiga que D. Pedro dirige ao tal Mestre não identificado, que não seria, pois, Estêvão Vasques Pimentel, mas sim este mesmo D. Álvaro, já mestre dos Hospitalários (o que, do ponto de vista da sua vida pessoal, e atendendo às dezenas de filhos que teve, não seria descabido, face ao que nos diz a cantiga ${ }^{48}$. Seja como for, esta hipótese de um ataque indirecto aos Pereira, muito plausível no cenário político em que actua esta última geração de trovadores, não deixaria assim de entrar em irónico contraste com o evidente programa de engrandecimento da linhagem e, muito particularmente da figura

\footnotetext{
${ }^{47}$ Como sugere José Mattoso, de novo na introdução à sua edição da obra, é possível que este parágrafo tenha sido acrescentado pelo refundidor de 1380-83 (ob. cit., p. 43).

48 Já depois de terminado e entregue este artigo, Cláudio Neto, no âmbito da investigação que está a desenvolver sobre as Ordens Militares, recolheu alguns dados novos, que parecem tornar plausível a identificação deste mestre com um dos irmãos Escacho, Pedro Peres ou Garcia Peres, que encontramos em momentos sucessivos à frente da Ordem de Santiago (1319-1329 e 1329-1346), talvez mais possivelmente o segundo, próximo de Afonso IV. Este hipótese baseia-se no facto de serem figuras com ligações atestadas a Lisboa. Note-se ainda que Pedro Escacho foi, em 1313, alvazil de Lisboa, em parceria com um João da Arruda, que poderia eventualmente ser irmão do Pedro da Arruda a quem Estêvão da Guarda dirige uma cantiga ("Pois a todos avorrece").
} 
do mesmo D. Álvaro (o pai de D. Nuno Álvares Pereira), o herói da longa narrativa da batalha do Salado incluída no Nobiliário do Conde D. Pedro, mas a ele acrescentada, como se sabe, pelo refundidor de $1380-83^{49}$.

Finalmente, quanto à linhagem dos Cunha, eventualmente atacada na pessoa de Martim Vasques da Cunha, trata-se de uma sugestão, mas que toma como ponto de partida um outro ciclo de cantigas desta última geração (três composições de Estêvão da Guarda e uma do Conde D. Pedro), ciclo este dirigido a um Martim Vasques, clérigo, jogral e astrólogo. Mais uma vez, pensamos que a insistência poderá indicar mais do que mera zombaria pessoal. E na verdade, José Augusto Pizarro faz referência a um clérigo com este nome, prior de Tábua (terra, por excelência, dos Cunha), cujos (avultados) bens são comprados em 1362, já depois da sua morte, pelo filho de Martim Vasques da Cunha, Vasco Martins ${ }^{50}$. Os dois Martim Vasques (o da Cunha e o prior) pertenceriam, pois, certamente, à mesma geração. Este Martim Vasques da Cunha era, de resto, genro de Lopo Fernandes Pacheco, um dos grandes validos de Afonso IV. Pensamos, pois, que todos estes dados (e mesmo, eventualmente, a homonímia) tornam plausível que as alusões feitas nas composições dirigidas ao clérigo (as pelejas em que "foi mal chagado", a igreja prometida, a sua passagem de Lisboa a "além-Douro") possam ser, na verdade, zombarias indirectas, e de novo politicamente orientadas contra os próximos de Afonso IV (provavelmente ainda infante, uma vez que a figura do clérigo é a de um jovem à procura de colocação ${ }^{51}$ ).

Certamente, muito mais haveria a dizer sobre esta matéria. Não pretendendo alongar excessivamente estas notas, termino este ponto regressando exactamente ao que disse no

\footnotetext{
${ }^{49}$ Na discussão da identidade deste refundidor, José Mattoso (ob. cit., p. 50) coloca como hipótese a de se tratar de alguém ao serviço dos descendentes de um tio de D. Álvaro, Rui Gonçalves Pereira, vassalo do Conde D. Pedro e nomeado como um dos seus testamenteiros (1350). A este propósito, chamamos apenas a atenção para a cantiga de Estêvão da Guarda, na qual é referido um Rui Gonçalves (como autor de uma cantiga, a qual, a ter sido feita, não chegou até nós). Na nota antroponímica respectiva, entre as várias hipóteses para a sua identificação, avançamos a de Rui Gonçalves Pereira (acrescente-se, no entanto, que o Nobiliário refere dois Rui Gonçalves Pereira, ambos filhos bastardos de D. Gonçalo Pires Pereira). De resto, como anota o Prof. Mattoso com toda a razão, todas estas hipóteses dependerão "de saber o tipo de relações que existiriam entre eles e o prior do Hospital" (Mattoso refere-se aos descendentes do Rui Gonçalves que cita, mas, recuando para o tempo das cantigas, poderíamos alargar a dúvida a todos estes personagens; $\mathrm{o}$ assunto merecerá decerto uma atenção que aqui não lhe poderemos dar).

${ }_{50}$ Ob. cit., II, p. 970, nota 167.

${ }^{51}$ De resto, as repetidas referências, feitas por Estêvão da Guarda numa das cantigas, à "coroa" do clérigo talvez possam ter um sentido equívoco.
} 
seu início sobre a renovada constatação, que fomos adquirindo ao longo do nosso trabalho, da ligação estreita das cantigas trovadorescos com os contextos da sua produção, nomeadamente com os contextos políticos. Como é evidente, nem sempre possuímos hoje os dados que nos permitam estabelecer uma ligação exacta, ou os que possuímos ou pressupomos podem não ser suficientes para garantir que a interpretação avançada seja efectivamente a mais correcta. Trata-se, de qualquer forma, de cantigas, ou seja, de fontes particulares onde, como disse, a estratégia política, quando existe ou parece existir, é sempre indissociável da estratégia artística. E a estratégia artística, como é próprio deste campo, não apela à leitura referencial imediata mas à interpretação - como os próprios trovadores, aliás, pressupunham, eles que ao equívoco e a outros recursos semelhantes iam buscar uma parte substancial da sua arte de "bem dizer mal" (e zombando até, por várias vezes no nosso corpus, dos que, por falta de subtileza ou de cultura, os não entendem). Em relação a uma parte das cantigas, dificilmente poderemos ter certezas, pois, no que toca às interpretações avançadas, sobretudo hoje que não dispomos dos implícitos que eram acessíveis aos ouvintes da época. Seja como for, o certo é que a investigação que desenvolvemos, sobretudo no que toca às figuras nelas referidas, conduziu geralmente a dados que pareciam confirmar alguma forma de enquadramento político para muitas das composições que até agora não tinham sido encaradas neste prisma. Neste sentido, estou certa de que, talvez com a excepção das soldadeiras, uma parte das figuras que não fomos capazes de localizar (como Pedro Bom ou Pero Ordoñez, na corte de Afonso X, ou Rui Gonçalves e João Eanes, nesta última geração portuguesa, entre muitas outras) serão também, muito plausivelmente, os protagonistas de "cantigas situadas", que esperam apenas que uma investigação mais atenta ou perspicaz os localize para podermos entrar, também nós, no jogo trovadoresco, e tentar interpretar, com maior ou menor segurança, a situação.

\section{Perspectivas futuras}

$\mathrm{Na}$ sua configuração actual, a base de dados "Cantigas Medievais" é, pois, uma plataforma cujos múltiplos dados procurámos que fossem o mais actualizados possível, mas cujo carácter não fechado gostaria de realçar. Na verdade, as possibilidades de reformulação imediata e contínua dos dados introduzidos, bem como de adição de 
informação nova de toda a ordem constituem, por si mesmas, um enquadramento a todos os títulos aliciante para a investigação. Assim sendo, a equipa que desenvolveu este projecto considera que o site presentemente online representa apenas a primeira parte de um trabalho que, dentro das suas possibilidades (e também da existência ou não de eventuais financiamentos), espera poder vir completar e a desenvolver em várias outras vertentes, num futuro mais ou menos próximo. Neste sentido, e para além da correcção dos dados actuais, ou mesmo o seu alargamento, sempre que novas informações resultantes da investigação estiverem disponíveis, tarefa que esperamos poder efectuar regularmente ${ }^{52}$, a equipa projecta também completar insuficiências evidentes, e mesmo alargar a base a outros campos que não puderam ser considerados nesta fase, como sejam, e passo a citar apenas alguns deles:

- no que toca à edição dos textos, a necessária indicação das leituras anteriores de que cada um foi objecto até à data;

- no que toca à informação referente a cada cantiga, a indicação das suas características formais (estróficas, rimáticas, expressivas, entre muitas outras), bem como, no que toca ao corpus global, a sinalização, tanto quanto possível exaustiva, das cantigas de seguir, matérias sobre a quais a presente BD é, para dizer o mínimo, muito parca;

- de resto, e porque as cantigas galego-portuguesas fazem parte, e por vezes explicitamente, do movimento mais geral do trovadorismo europeu, a sinalização das relações intertextuais que muitas composições estabelecem com textos de outras proveniências, nomeadamente com os textos provençais e franceses;

- no que toca à "Arte de Trovar", uma explicação mais detalhada de cada título e capítulo;

- na área dos manuscritos, a inclusão de todas as anotações e sinais gráficos que Ângelo Colocci profusamente distribuiu ao longo do Cancioneiro da Biblioteca Nacional; a

\footnotetext{
${ }^{52}$ Neste sentido, chamamos a atenção para a página “Atualizações recentes”, acessível a partir da página de entrada, e onde vamos anotando todas as alterações ou novos dados introduzidos na base. Sendo certo que, no caso das alterações (que não sejam meras correcções de ligeiros lapsos), consideramos útil deixar um registo das versões anteriores, a equipa fará um esforço no sentido de as deixar registadas nesta página.
} 
inclusão da Tavola Colocciana na BD; e uma abordagem mais exaustiva das iluminuras do Cancioneiro da Ajuda, bem como das restantes imagens presentes neste cancioneiro (a partir do seu estudo prévio);

- no que toca às pesquisas disponíveis na $\mathrm{BD}$, o seu alargamento a outras áreas, de momento ainda não contempladas por este poderoso recurso; neste aspecto, chamo a atenção para o carácter provisório da já referida "pesquisa temática", cujos temas e subtemas necessitarão certamente de afinação e alargamento;

- finalmente, e se bem que o site já permita a consulta de alguns dos seus dados em Inglês, a tradução de uma parte das próprias cantigas para esta língua faz igualmente parte dos planos da equipa a médio prazo.

Entendendo a base de dados como um projecto em construção, o meu desejo, pois, e certamente o de toda a equipa, é que o de que possamos desenvolver o trabalho já efectuado e o trabalho futuro num diálogo frutuoso com a comunidade científica que se interessa pelas cantigas, dos medievalistas aos especialistas das mais diversas áreas, já que será essa certamente a única forma de se avançar no conhecimento e na preservação informada do riquíssimo património que os trovadores e jograis ibéricos nos legaram.

\section{COMO CITAR ESTE ARTIGO}

\section{Referência electrónica:}

LOPES Graça Videira - “Algumas notas sobre a base de dados Cantigas Medievais Galego-Portuguesas". Medievalista [Em linha]. Nº12, (Julho - Dezembro 2012). [Consultado dd.mm.aaa]. Disponível em http://www2.fcsh.unl.pt/iem/medievalista/MEDIEVALISTA12ไlopes1202.html. ISSN 1646-740X. 
Algumas notas sobre a base de dados Cantigas Medievais Galego-Portuguesas • Graça Videira Lopes

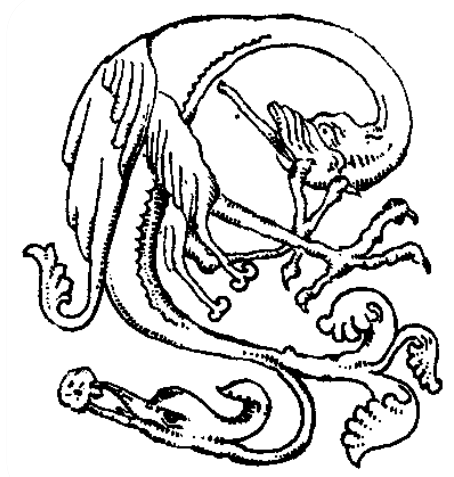

Medievalista online $N^{\circ} 12$ | Julho - Dezembro 2012 @ IEM - Instituto de Estudos Medievais 51 www2.fcsh.unl.pt/iem/medievalista 